\title{
Serviços Ecossistêmicos da Geodiversidade: Avaliação e propostas de valoração em locais de interesse geológico do Parque Nacional de Ubajara, Ceará, Brasil
}

\author{
Geodiversity Environmental Services: Evaluation and valuation proposals for sites of \\ geological interest in the Ubajara National Park, Ceará, Brazil
}

Suedio Alves Meira

Doutor em Geografia pela Universidade Federal do Ceará - UFC, Brasil suediomeira@gmail.com

Marcos Antonio Leite do Nascimento Professor Associado da Universidade Federal do Rio Grande do Norte - UFRN, Brasil marcos@geologia.ufrn.br

Edson Vicente da Silva Professor Titular da Universidade Federal do Ceará - UFC, Brasil cacauceara@gmail.com

María Teresa Echeverría Arnedo Professora Titular da Universidad de Zaragoza - Unizar, Espanha

mtecheve@unizar.es

\begin{abstract}
Resumo
A superexploração do capital natural pela sociedade atual consolida uma crise ambiental global. Diversas abordagens, dentre as quais a dos Serviços Ecossistêmicos, foram formuladas visando frear a degradação e fomentar medidas de conservação ambiental. Nesse contexto, esse trabalho analisa os bens e os serviços ecossistêmicos prestados por elementos da geodiversidade nos locais de interesse geológico (LIG) do Parque Nacional de Ubajara, Ceará, Brasil. A metodologia parte do inventário de LIGs, da avaliação quanti-qualitativa e da proposição de estratégias de valoração em âmbito local. Foram inventariados onze LIGs de relevância nacional que prestam diversos serviços ecossistêmicos. As propostas de valoração têm como alicerce a relação com os agentes econômicos e sociais locais, sendo passíveis de replicação em diferentes unidades de conservação brasileiras.
\end{abstract}

Palavras-chave: Serviços Ambientais; Geopatrimônio; Geoconservação.

\begin{abstract}
The natural capital overexploitation by contemporary society consolidates a global crisis. Several approaches, including those from Environmental Services, have been formulated aiming to diminish degradation and increment environmental conservation measures. In this context, this work analyses environmental goods and services provided by the geodiversity elements of sites of geological interest (LIG) in the Ubajara National Park, Ceará, Brazil. The methodology starts from the LIG inventory, the quantitative-qualitative evaluation and valorization propositions in a local scope. Eleven LIGs have been inventoried as of national relevance, which provides several ecosystem services. The valuation propositions have its foundations in relation with local economical and social agents, being replicable in different Brazilian conservation units.
\end{abstract}

Keywords: Environmental Services; Geoheritage; Geoconservation. 


\section{INTRODUÇÃO}

Para entender o atual panorama de crise ambiental global é necessário apreender como se deu a relação do ser humano com a natureza. Santos (1992) aborda que os primeiros grupos sociais mantinham uma relação "amigável” com a natureza, uma vez que a produção do espaço e da vida social respondiam às carências e aos desejos reais. A ampliação do sistema capitalista e a primordialidade de comércio entre as coletividades modificam essa relação ao introduzir "nexos novos e também novos desejos e necessidades e a organização da sociedade e do espaço tinha de se fazer segundo parâmetros estranhos às necessidades íntimas ao grupo" (SANTOS, 1992, p. 97).

O consumo, guiado por estratégias de marketing direto, indireto e institucionais, passa ser o mote das sociedades. Não é possível delimitar o começo desse paradigma, porém, o avanço do capitalismo pós revolução industrial é considerada o início do apogeu dessa nova conformação global que atinge o ápice após a Segunda Guerra Mundial, com a diversificação geográfica das atividades e a inserção de uma nova parcela da população global enquanto agente de compra.

Outro aspecto que influencia a mudança da relação sociedade e natureza é a evolução das Ciências que gera uma falsa ideia de que o ser humano tem o domínio total sobre o ambiente, refletindo numa crença da possibilidade de um crescimento econômico contínuo. O capital natural, que pode ser entendido enquanto o "estoque de recursos naturais existentes que gera um fluxo de serviços tangíveis e intangíveis, direta e indiretamente úteis aos seres humanos, conhecido como renda natural" (ANDRADE et al., 2012, p. 696), erroneamente passa a ser entendido como passível de substituição pelos produtos gerados pelo capital humano.

Esse contexto filosófico e metodológico resulta em uma superexploração do capital natural, ocasionando, como nunca antes na história, efeitos adversos diretos sobre os ecossistemas. Em meio a emergência global sobre as questões ambientais são formuladas diversas propostas embasadas na concepção de que a conservação da natureza e o desenvolvimento econômico configuram elementos complementares ao estabelecimento de uma biosfera estável e resiliente (GUERRY et al., 2015). São propostas que visam romper o entendimento do desenvolvimento econômico e da conservação ambiental enquanto objetivos antagônicos na gestão territorial e que dispõem o estabelecimento de um novo paradigma na relação sociedade e natureza.

Dentre o bojo de propostas está o da Economia dos Ecossistemas que apresenta como objetivo principal "a gestão eficiente e sustentável do capital natural, considerando este como um portfólio de ativos que rendem benefícios cruciais às atividades humanas" (ANDRADE; ROMEIRO, 2009, p. 2). O capital natural é assim a base para a continuidade da humanidade, uma vez que dependemos dos seus bens e serviços para o desenvolvimento das mais diversas atividades. 
A Economia dos Ecossistemas dispõe como fundamento teórico a concepção dos bens e serviços ecossistêmicos, entendidos enquanto os benefícios tangíveis e intangíveis obtidos pela humanidade por meio dos processos, dinâmicas e interações entre os componentes do capital natural (COSTANZA et al., 1997). Estudos relacionados aos bens e serviços ecossistêmicos têm ganhado popularidade no meio acadêmico após a Avaliação Ecossistêmica do Milênio, realizada em 2005, resultando em um aprofundamento metodológico e prático.

Mesmo com a evolução recente, ainda é difícil entender e quantificar a complexidade dos processos relacionados aos bens e serviços ecossistêmicos. Em meio aos esforços os componentes ambientais abióticos, integrantes da geodiversidade, apresentam pouco enfoque, uma vez que componentes bióticos, em especial a vegetação, ganham notoriedade. Entendendo essa fragilidade, autores como Gordon e Barron (2012) e Gray (2013) discutem a necessidade e propõem formas de pensar o papel da geodiversidade nesse novo paradigma.

Nesse contexto, o presente trabalho tem como objetivo principal analisar os bens e serviços ecossistêmicos prestados por elementos da geodiversidade presentes em locais de interesse geológico do Parque Nacional de Ubajara (PNU), Ceará, Brasil (Figura 1).

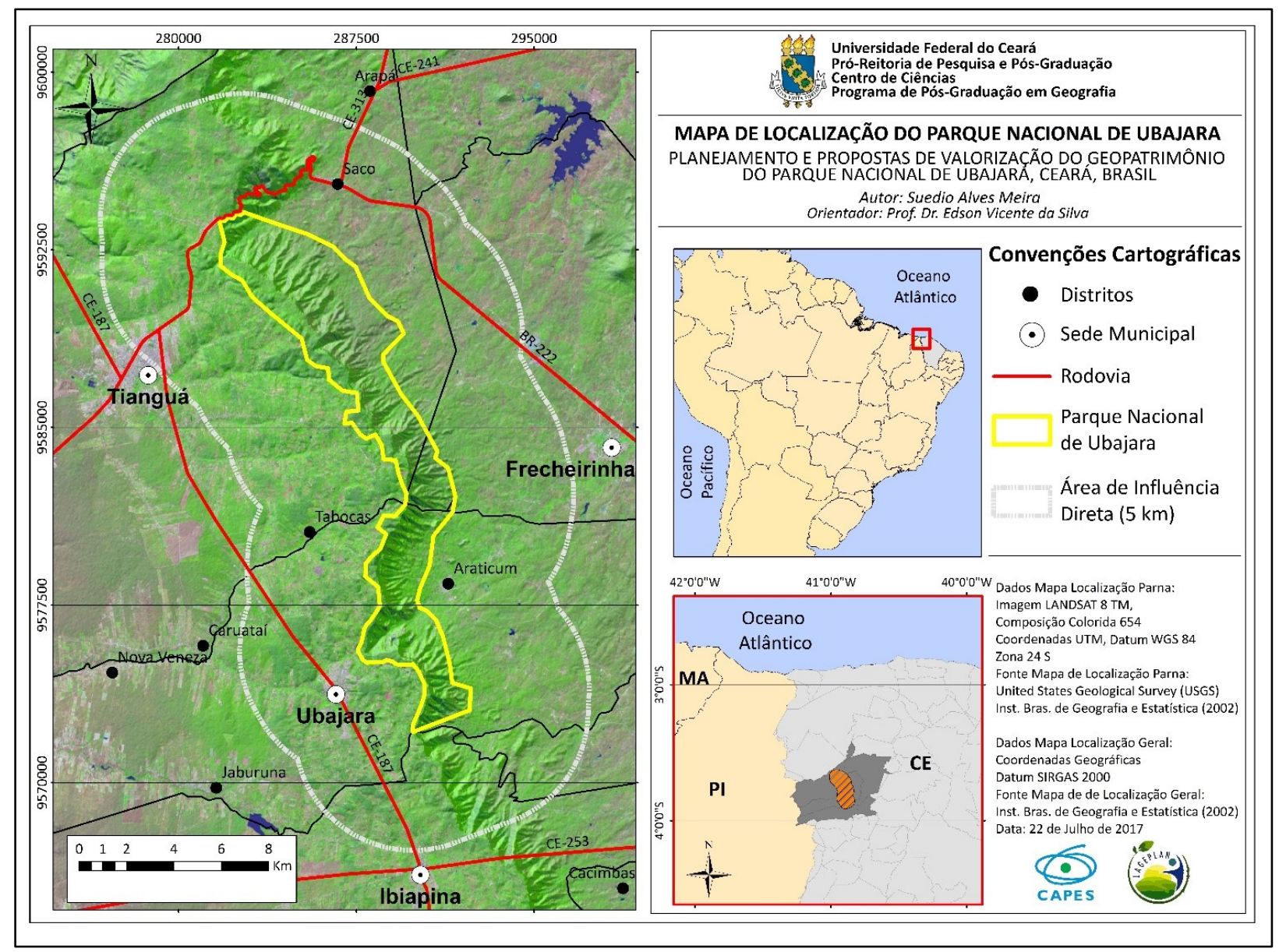

Figura 1 - Mapa de localização do Parque Nacional de Ubajara, Ceará, Brasil. Autor: Suedio Alves Meira, 2017. 
Como objetivo complementar o estudo traz um conjunto de propostas que pensam a valoração dos bens e serviços ecossistêmicos a nível local, buscando integrar as comunidades circundante e os visitantes em ações diretas e indiretas de conservação ambiental. Com base em estratégias de pagamento por serviços ambientais, geralmente aplicadas a níveis estaduais ou nacionais, as propostas realizam uma análise de detalhe sobre as potencialidades existentes e como as mesmas podem ser revertidas em recursos monetários e humanos em prol da conservação ambiental da unidade de conservação (UC).

O PNU foi instituído no dia 30 de abril de 1959, sendo uma das mais antigas UC brasileira, com a finalidade de garantir a integridade e os processos evolutivos do excepcional conjunto de formações geológicas e biológicas presentes. Atualmente o PNU conta 6.288 hectares, em engloba áreas dos municípios de Frecheirinha, Tianguá e Ubajara (Figura 1). A geodiversidade local é caracterizada pelo principal conjunto de feições cársticas do estado Ceará e pelo contato do Glint da Ibiapaba e a Depressão Sertaneja, originando feições escarpadas de grande beleza cênica.

\section{METODOLOGIA}

Os pressupostos metodológicos que orientam o presente trabalho partem do arcabouço teórico da temática da Geodiversidade (GRAY, 2013). Em um primeiro momento realizou-se um extenso levantamento bibliográfico em artigos, bancos de dissertações e teses, documentos institucionais e livros. Conceitos como os de capital natural, serviços ecossistêmicos, pagamentos por serviços ambientais e as relações desses como os componentes da geodiversidade configuraram o escopo da pesquisa.

A etapa seguinte partiu da realização de trabalhos de campo para o inventário dos Locais de Interesse Geológico (LIGs) do Parque Nacional de Ubajara, segundo critérios educativos e turísticos. O inventário foi realizado por meio da união das metodologias de seleção de locais com caraterísticas superlativas e a de classificação segundo categorias temáticas pré-estabelecidas (framework), constituindo um inventário sistemático. Foi possível realizar o inventário tendo como base locais elencados na literatura, juntamente com observações e percepções oriundas dos trabalhos de campo. Assim, realizou-se o que Sharples (2002) reconhece por "inventário de reconhecimento". Foram definidos três frameworks para o Parque Nacional de Ubajara segundo critérios cronoestratigráfico e geomorfológicos: i) Zona com coberturas cenozoicas; ii) Coberturas paleozoicas; iii) Embasamento neoproterozoico.

A avaliação quantitativa dos LIGs foi realizada seguindo parâmetros do Sistema de Cadastro e Quantificação de Geossítios e Sítios da Geodiversidade (GEOSSIT) do Serviço Geológico Brasileiro (CPRM, 2019), uma adaptação das propostas de Garcia-Cortés e Carcavilla- 
Urquí (2013) e Brilha (2016). Essa metodologia faz parte de um esforço de unificação do inventário e da avaliação dos sítios geológicos brasileiros, e determina critérios na definição dos valores científico, educativo e turístico, sendo atribuídos graus de relevância. Os valores de uso são balizados pela avaliação do risco de degradação e a prioridade de proteção.

Como foco principal foi concretizada uma avaliação de cunho qualitativo com base na proposta dos serviços ecossistêmicos prestados pela geodiversidade (GRAY, 2013). A avaliação buscou entender quais os bens e serviços prestados pelos elementos abióticos presentes nos LIGs inventariados. Com base nessa avaliação foram construídas propostas de valoração ambiental (pagamentos por serviços ambientais) de âmbito local. São sugeridos diferentes projetos que visam a angariação de recursos financeiros e a conservação ambiental do PNU com base no envolvimento da população e dos agentes econômicos locais.

\section{SERVIÇOS ECOSSISTÊMICOS: BREVE OLHAR SOBRE A GEODIVERSIDADE}

Os bens e serviços ecossistêmicos ou serviços ambientais apresentam uma diversidade de definições conceituais, mas que convergem para o conjunto de benefícios tangíveis e/ou intangíveis que os componentes ambientais (capital natural) fornecem, de forma direta ou indiretamente, à humanidade (COSTANZA et al., 1997; HERCOWITZ et al., 2009; ANDRADE et al, 2012; SILVA e NASCIMENTO, 2019). Os estudos que empregam a noção de serviços ecossistêmicos apresentam papel importante na efetivação do desenvolvimento sustentável, concebido enquanto o conjunto de ações alicerçado na conservação ambiental, melhoria econômica e promoção sociocultural.

A temática aproxima abordagens da economia e da sociologia ao arcabouço teórico e prático da conservação ao discutir a natureza enquanto capital natural. As diferentes linguagens adotadas na formulação dos métodos de valoração ambiental resultam no emprego em documentos e normativas de gestão territorial, transcendendo ao campo das discussões teóricas e possibilitando um contributo real à conservação ambiental.

As abordagens dos serviços ecossistêmicos são realizadas com base no princípio da precaução, uma vez que envolvem um grau de incerteza diante a diversidade de variáveis que integram a dinâmica ambiental. O princípio supracitado visa a adoção de uma precaução cética assumindo que é possível a ocorrência de problemas futuros relacionados à falta de capital natural, mas sempre deixando "aberta as possibilidades de que os mesmos sejam solucionados e de que não sejam tão graves como inicialmente previstos" sendo que a adoção dessa postura deve ocorrer “independentemente da visão otimista ou pessimista em relação ao futuro" (ANDRADE; ROMEIRO, 2009, p. 10). Andrade e Romeiro (2009, p. 10) salientam que 
Tal estratégia não pressupõe o desestímulo a novas tecnologias e a aversão total aos riscos envolvidos. Ao contrário, ela advoga o gerenciamento apropriado dos riscos, em linha com seus potenciais benefícios, custos e incertezas, não comprometendo a saúde das populações humanas e dos ecossistemas.

Essa forma de interpretação do capital natural e dos serviços prestados é necessária porque uma das estratégias de conservação suscitadas pela Economia dos Ecossistemas é o incentivo ao Pagamentos por Serviços Ambientais (ou, ecossistêmicos). O Pagamento por Serviços Ambientais configura arranjos institucionais que institui compensações em decorrência de algum bem ou serviço prestados pelo capital natural, essas compensações podendo ser de diversos tipos como "transferências diretas de recursos financeiros, apoio na obtenção de créditos, isenções fiscais e tarifárias, preferências para a obtenção de serviços públicos, acesso às tecnologias e treinamento técnico e subsídios" (HERCOWITZ et al., 2009, p. 140).

Diante o apresentado surge uma questão, quais as tipologias de serviços ecossistêmicos existentes e que podem ser "comercializadas" enquanto uma estratégia de conservação ambiental? A Avaliação Ecossistêmica do Milênio propôs uma classificação dos serviços ecossistêmicos em quatro categorias fundamentais: suporte, provisão, cultural e regulação. Os serviços de suporte possibilitam as condições ambientais necessárias ao incremento dos demais serviços, apresentam como características o fato de ocorrer de forma majoritária de maneira indireta e se manifestar em longo prazo (PARRON; GARCIA, 2015).

Os serviços de provisão "compreendem os produtos obtidos dos ecossistemas e que são oferecidos diretamente à sociedade, como alimentos e fibras naturais, madeira para combustível, água, material genético, entre outros" (PARRON; GARCIA, 2015, p. 31). Os serviços de regulação, como o nome sugere, englobam os benefícios vindos da regulação natural dos processos ambientais. Os serviços culturais são os benefícios que contribuem ao bem-estar da sociedade e a configuração da sua identidade.

Quando analisado o papel dos componentes ambientais de caráter abiótico, que abarcam a geodiversidade, no contexto dos serviços ambientais é possível perceber que os mesmos aparecem atrelados ao serviço de suporte. Em suma, a geodiversidade é reduzida à ideia de habitat. Essa abordagem configura um erro, uma vez que a geodiversidade oferece toda uma gama de bens e serviços à sociedade, os quais devem estar integrados e quantificados no âmbito dos arranjos institucionais que visam o Pagamento por Serviços Ambientais.

Visando preencher essa lacuna, Gray (2013) traz uma abordagem denominada de serviços ecossistêmicos da geodiversidade, que tem por objetivo é salientar os potenciais de uso dos elementos abiótico. Gray (2013) adota um sistema de classificação dos serviços ambientais da geodiversidade análogo ao proposto pela Avaliação Ecossistêmica do Milênio, porém, acrescenta a noção de serviços de conhecimentos, ao entender que um dos potenciais da geodiversidade é servir 
enquanto registro da história do Planeta, enquanto uma sala de aula ao ar livre. Assim, segundo Gray (2013) a geodiversidade apresenta um valor (intrínseco) e presta à sociedade cinco serviços (regulação, suporte, provisão, cultural e conhecimento) e 25 bens e processos (Figura 2).

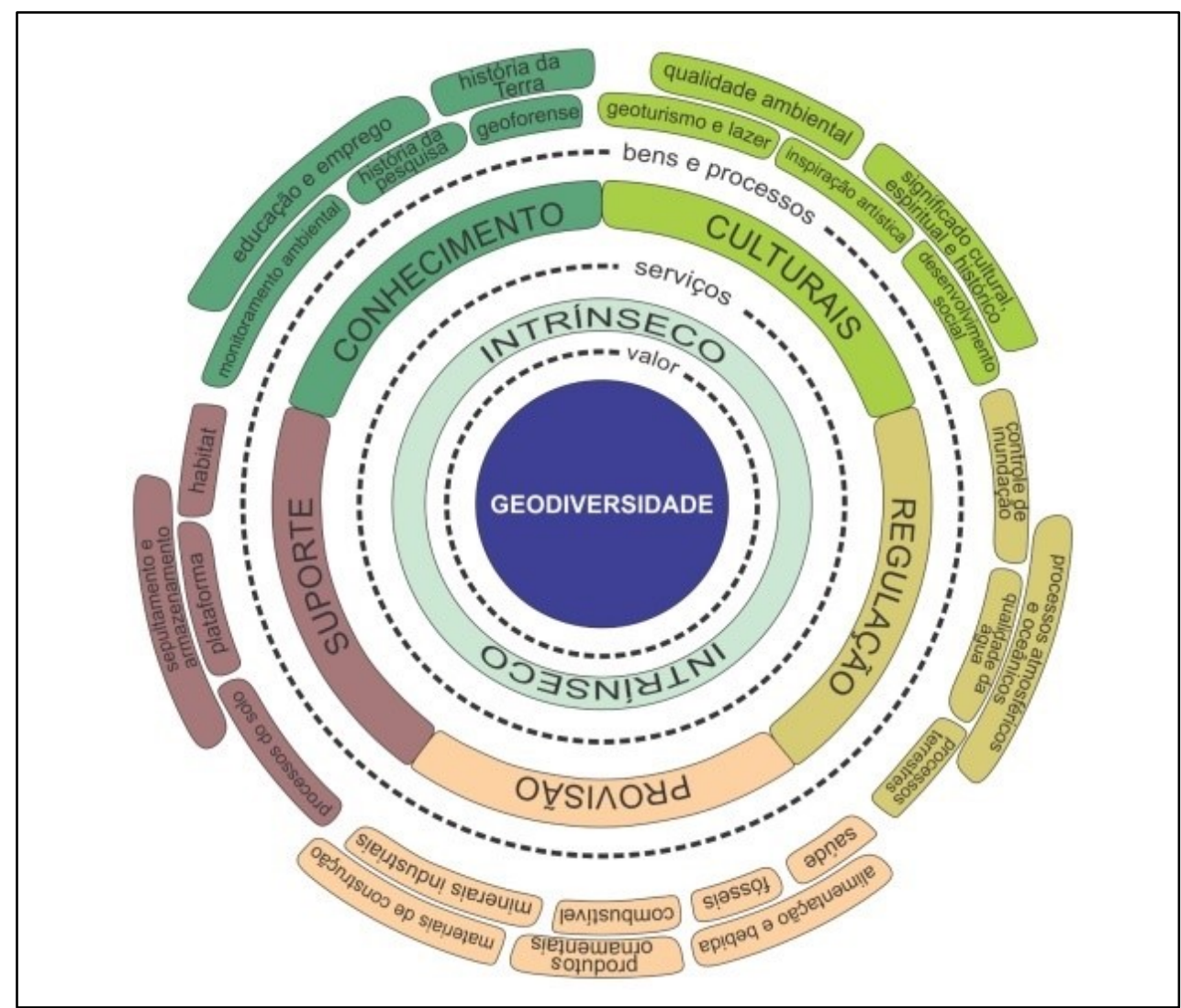

Figura 2 - Diagrama dos serviços ecossistêmicos da geodiversidade segundo Gray (2013).

Fonte: Silva e Nascimento (2016, p. 343).

A importância está na formulação teórica e metodológica de uma equiparação dos componentes ambientais, ou seja, uma abordagem que entende tanto os elementos vivos como os não vivos enquanto peças fundamentais no fluxo de matéria e energia que configuram os serviços ecossistêmicos. Para a efetivação de uma conservação, em sentido amplo, é necessário entender o potencial de uso da geodiversidade e da biodiversidade, bem como as relações existentes entre elas.

\section{INVENTÁRIO E AVALIAÇÃO DOS LOCAIS DE INTERESSE GEOLÓGICO DO PARQUE NACIONAL DE UBAJARA: BREVE ABORDAGEM}

O Parque Nacional de Ubajara é um mosaico paisagístico, cuja a diversidade é justificada por sua localização privilegiada entre dois domínios tectônicos. A porção leste abarca a Província Borborema, Subdomínio do Médio Coreaú, com litologias compostas por rochas metamórficas neoproterozoicas pertencentes ao Grupo Ubajara e à Formação São Joaquim. A geomorfologia é caracterizada por superfícies aplainadas da Depressão Sertaneja Ocidental do Ceará, apresentando menores índices pluviométricos e vegetação de caatinga arbórea-arbustiva (Figura 3). 
No extremo norte do PNU está a Formação São Joaquim (Figura 3), que segundo Siqueira (2011, p. 21) é composta por "quartzitos com variável composição mineralógica, incluindo minerais como cianita, silimanita e muscovita com intercalações menores de calcissilicáticas, xistos e metavulcânicas félsicas". O Grupo Ubajara é uma sequência vulcanossedimentar plataformal composta pelas Formações Caiçaras, Trapiá-Frecheirinha e Coreaú (CAVALCANTE, 1993). No perímetro do PNU o Grupo Ubajara está representado pelas formações Coreaú e Frecheirinha, sendo na área de influência delimitada, ocorre as formações Caiçaras e Trapiá (Figura 3).

Na porção oeste ocorre o domínio tectônico da Província Parnaíba, compreendendo rochas sedimentares do Grupo Serra Grande, base da Bacia do Sedimentar do Parnaíba. O Grupo Serra Grande, de idade Siluriana, está sobreposto ao embasamento cristalino (VAZ et al., 2007), sendo subdividido em formação Ipu, Tianguá e Jaicós (CAPUTO; LIMA, 1984). Essas rochas sedimentares sustentam o Glint da Ibiapaba, relevo que possibilita o desenvolvimento de chuvas orográficas e a fixação de uma mata plúvio-nebular de porte elevado. Essa área de front de bacia sedimentar expõe feições geomorfológicas características como escarpas, anfiteatros erosivos, bem como um grande número de cachoeiras.
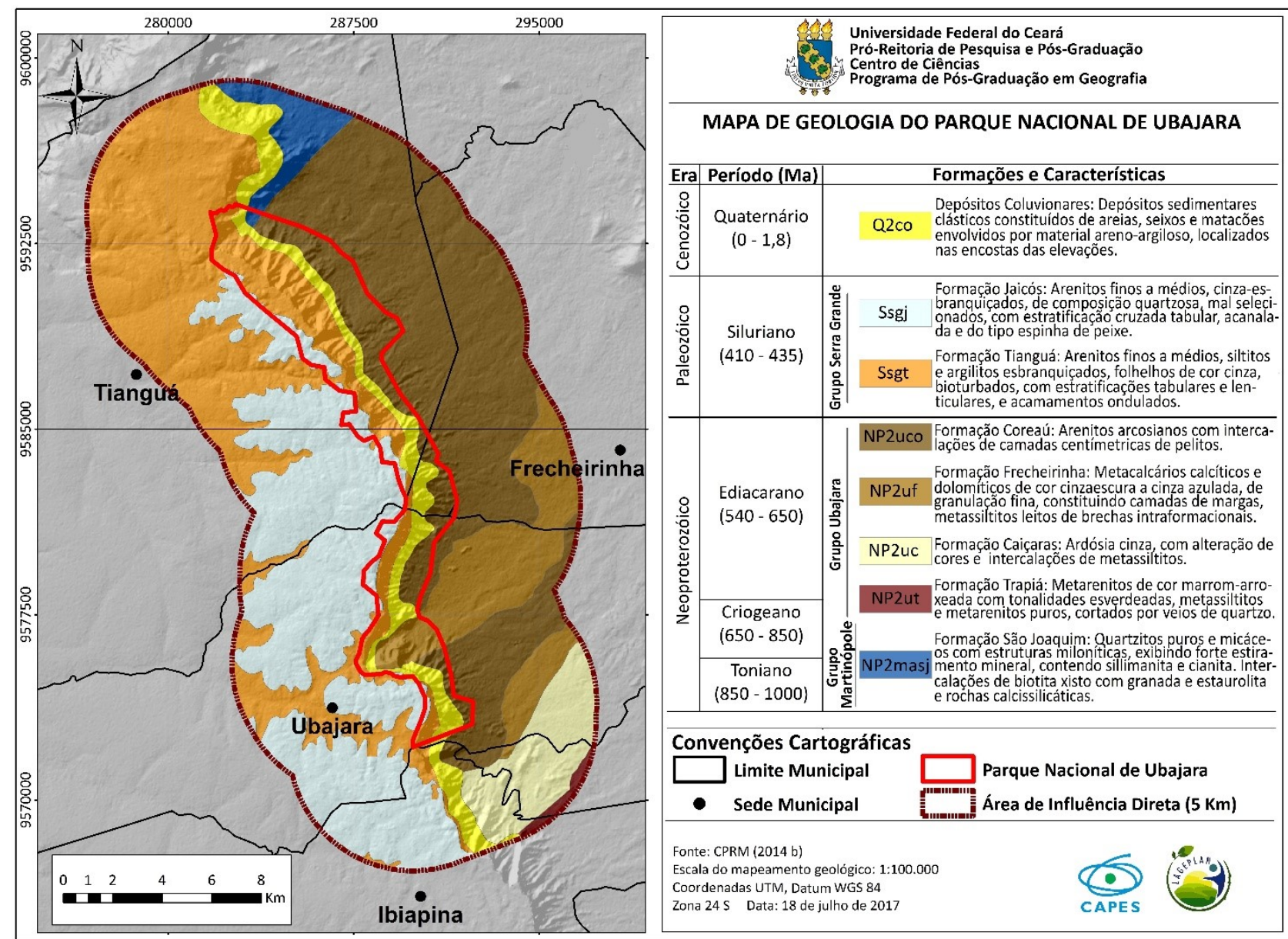

Figura 3 - Mapa geológico em escala 1:100.000 do Parque Nacional de Ubajara, Ceará, Brasil.

Autor: Suedio Alves Meira, 2017. 
A localização privilegiada do PNU permite uma diferenciação altimétrica superior à 700 . Nos locais mais elevados do Glint da Ibiapaba ocorrem altitudes superiores aos 900 metros e as áreas rebaixadas da Depressão Sertaneja ficam em torno dos 200 metros. Essa diferenciação topográfica confere uma variedade de ambientes geomorfológicos, refletindo em aspectos como solo, clima e vegetação.

O PNU é marcado por uma rica geodiversidade que reflete nos serviços ambientais prestado pelo capital natural e conta a história geológica e geomorfológica do noroeste cearense. Muitos desses elementos ou conjuntos desses elementos apresentam valor excepcional no caráter cientifico, educativo e/ou turístico. Sendo assim, foi realizado o inventário e a avaliação dos locais de interesse geológico. O inventário revelou onze locais de interesse geológico (LIG) (Figura 4) no perímetro e áreas adjacentes do PNU.

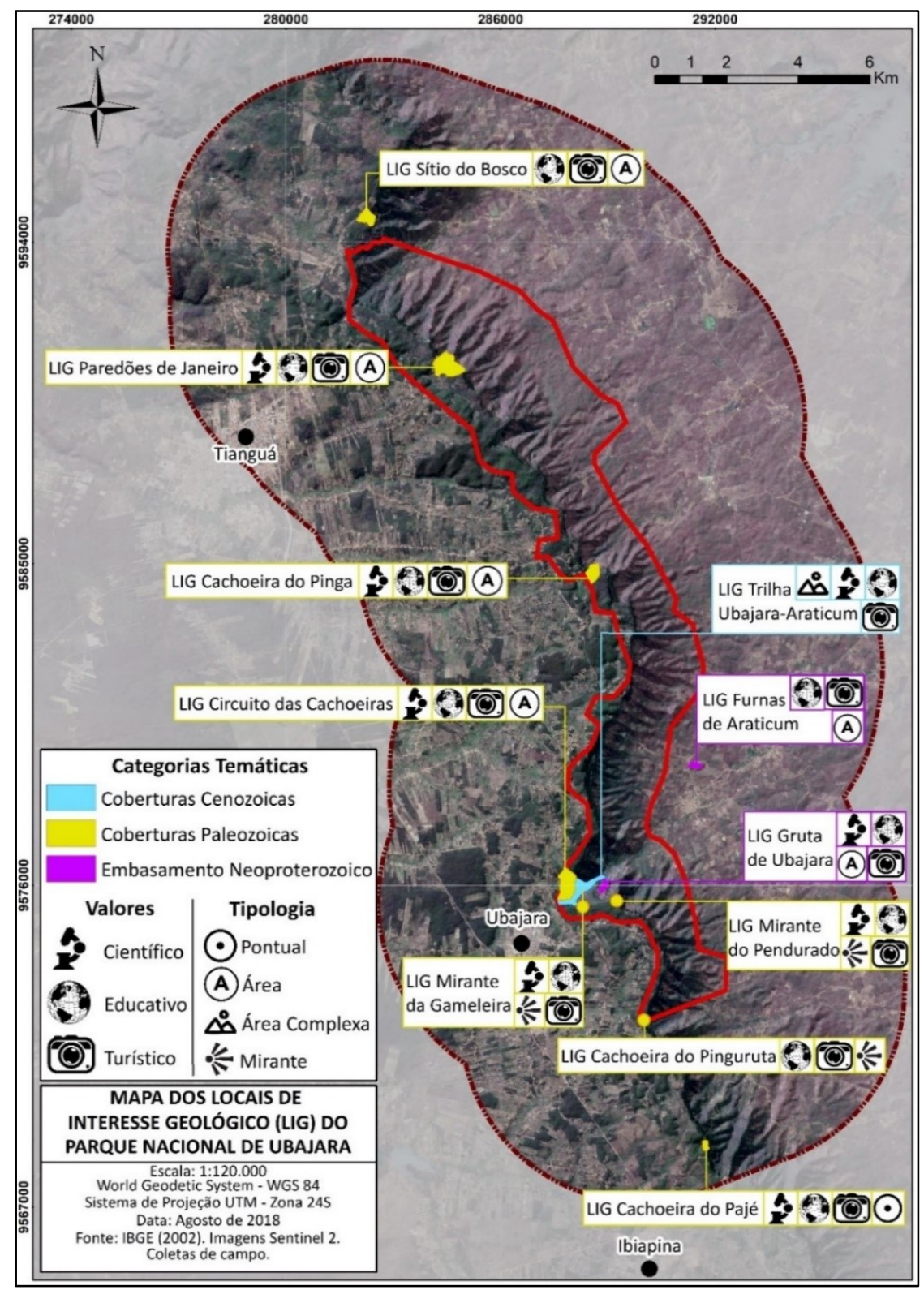

Figura 4 - Mapa de disposição dos Locais de Interesse Geológico do Parque Nacional de Ubajara, Ceará, Brasil. Autor: Suedio Alves Meira, 2018. 
O LIG Trilha Ubajara-Araticum (Figura 5a) abarca um caminho que liga o topo da Ibiapaba à Depressão Sertaneja. Devido a diferença hipsométrica de 371 metros são distinguidas fáceis da Formação Tianguá e afloramentos das Formações Caiçaras e Frecheirinha. O LIG ainda dispõe de icnofósseis em rochas da Formação Tianguá e vista panorâmica para a base da Cachoeira do Cafundó. O LIG Sítio do Bosco apresenta fácil acesso e boa visibilidade dos elementos geológicos, há pontos onde é possível tocar a rocha, o que possibilita o uso tátil do LIG. Três locais que atribuem interesse geológico, o mirante da rampa de parapente, e seu aspecto panorâmico, os paredões rochosos da trilha da Caverna do Morcego e a própria Caverna do Morcego (Figura 5b).

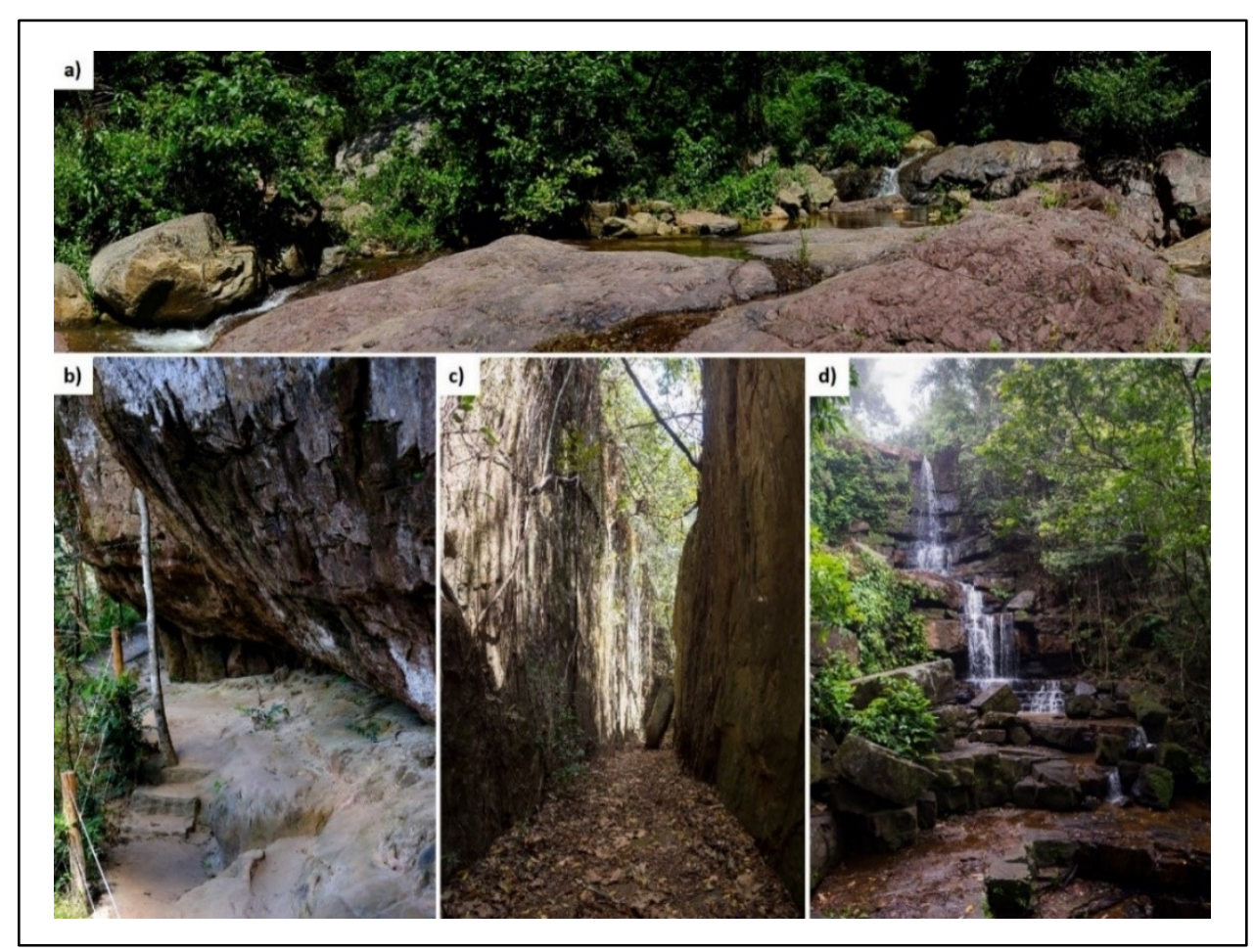

Figura 5 - a) Afloramento de ardósias no LIG Trilha Ubajara Araticum. b) Paredões em arenitos da Formação Tianguá no LIG Sítio do Bosco. c) Fendas estruturais em rochas sedimentares do LIG Paredões de Janeiro. d) O LIG Cachoeira do Pinga respondendo às camadas sedimentares e rede de diáclese da Formação Tianguá

Fotos: Suedio Alves Meira, 2020

O LIG Paredões de Janeiro oferece como diferencial a presença de fendas estruturais em meio aos arenitos da Formação Tianguá, são quatro grandes incisões que chegam a ultrapassar os 150 metros de comprimento e 20 metros de altura (Figura 5c). Para além disso, há dois mirantes em frente a anfiteatros erosivos e uma cachoeira. O LIG Cachoeira do Pinga (Figura 5d) é caracterizado por uma cachoeira em degraus que corta as camadas sedimentares do Grupo Serra Grande e expõe uma leve inclinação para interior da Bacia do Parnaíba, característica de borda de bacias.

Os LIGs Mirante da Gameleira (Figura 6a) e Mirante do Pendurado (Figura 6b) estão localizados próximos ao centro de visitantes do PNU, sendo espaços destinados à pratica turística e à educação ambiental. No Mirante da Gameleira os principais temas passíveis de abordagem partem do trabalho hídrico na evolução do relevo e a visualização de até quatro cachoeiras (Cachoeiras da 
Gameleira, do Cafundó, do Gavião e da Murimbeca). No Mirante do Pendurado é possível discutir sobre a evolução regional do relevo e aspectos morfológicos exocársticos, caracterizados pelos cones cársticos esculpidos em rochas matacalcárias da Formação Frecheirinha.

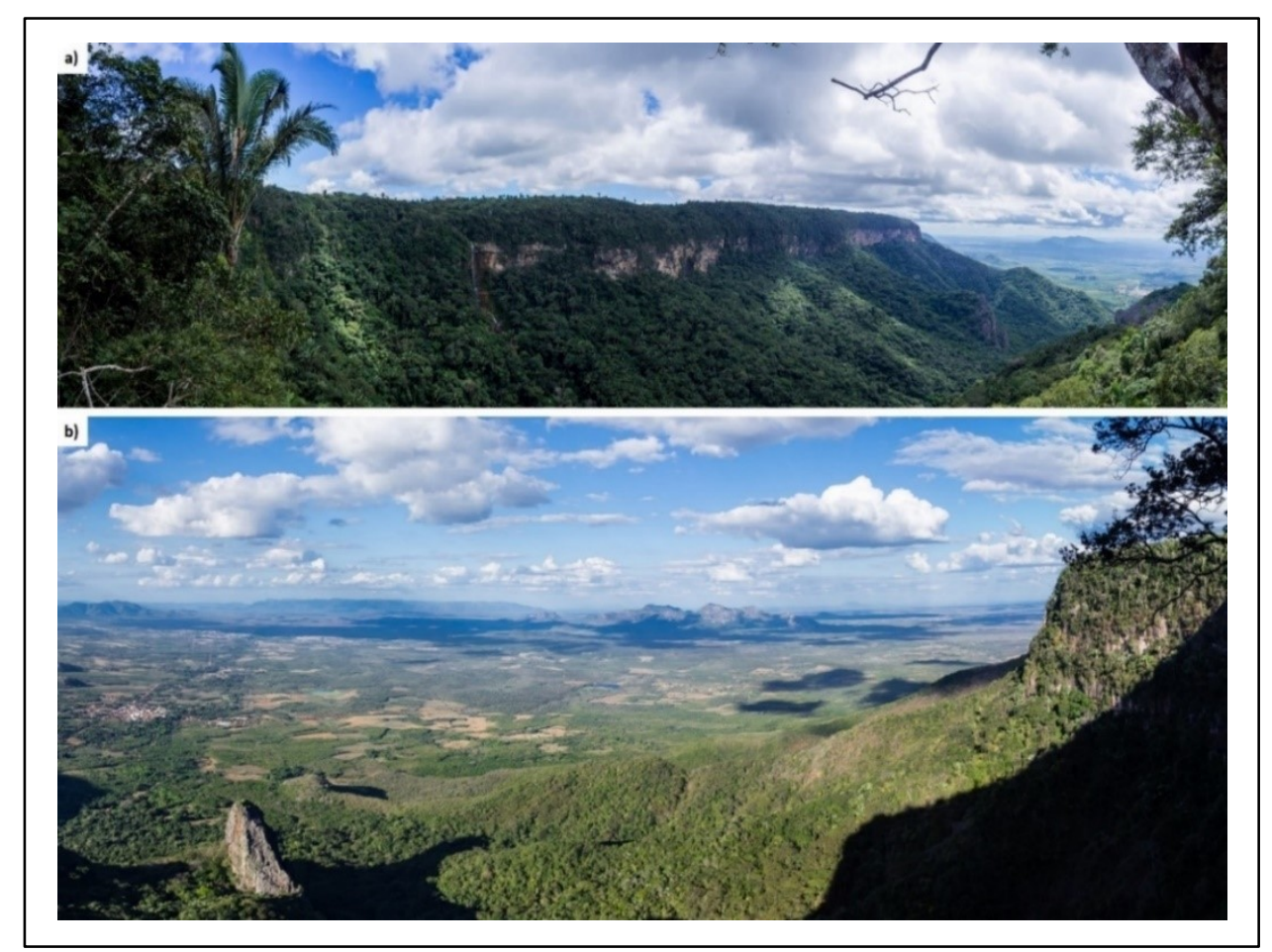

Figura 6 - a) Anfiteatro erosivo escarpado com presença de cachoeiras e cones cársticos do LIG Mirante da Gameleira. b) Vista da zona de escarpa e depressão sertaneja desde o LIG Mirando do Pendurado.

Fotos: Suedio Alves Meira, 2020.

O LIG Cachoeira do Pinguruta (Figura 7a) também configura um mirante para as feições do Glint da Ibiapaba e da Depressão Sertaneja, a fácil interpretação da zona de escarpa e a visualização do maciço do Carmutim, em meio à área rebaixada da depressão, configuram os principais pontos de abordagem. O LIG Cachoeira do Pajé (Figura 7b) é marcado por uma cachoeira que acompanha uma rede de diaclases presente no arenito, essas áreas de fragilidade permitem a gênese de abrigos sobre rochas, frutos de solapamentos. O LIG está no contato entre rochas das formações Tianguá e Jaicós, exibindo um arenito esbranquiçado com concreções ferruginosas em fraturas que seguem o plano das camadas. Nas zonas fraturadas ocorrem a aglomeração de material argiloso proveniente da zona saprolítica e o desenvolvimento de pequenos coraloides em decorrência da capilaridade.

O LIG Circuito das Cachoeiras engloba as cachoeiras do Canfundó e do Gavião (Figura 7c). O potencial educativo e turístico do local é expresso pelo entalhamento dos leitos dos riachos Boa Vista e Gavião em rochas da formação Tianguá, formando vales encaixados que expõem o acamamento sedimentar, e pela morfologia das cachoeiras, que refletem uma complexa evolução geomorfológica orientada pela diferenciação litológica local. 


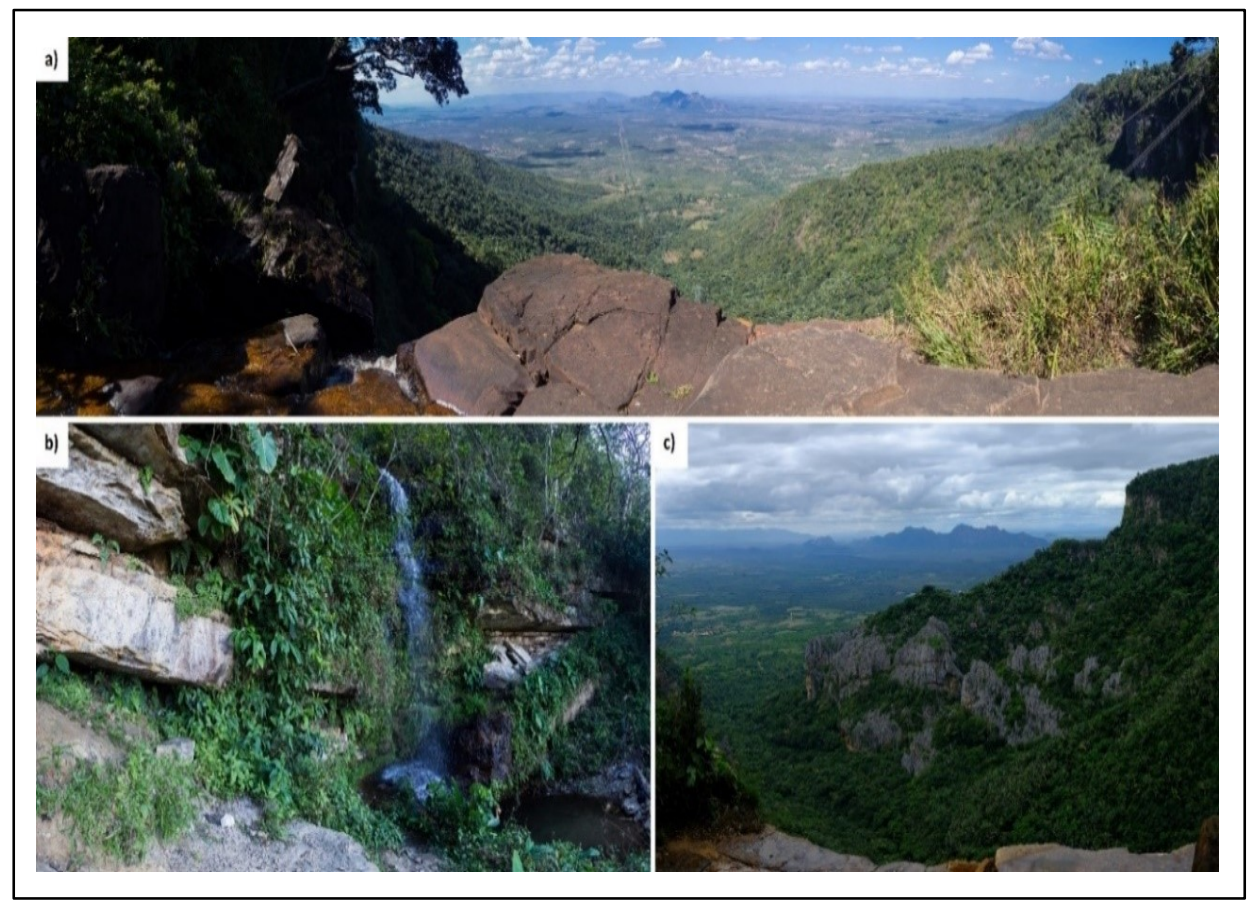

Figura 7 - a) Vista panorâmica do LIG Cachoeira do Pinguruta. b) Camadas sedimentares e presença de abrigos sobre rocha no LIG Cachoeira do Pajé. c) Vista do cone carstico Morro de Ubajara desde o LIG Circuito das Cachoeiras.

Fotos: Suedio Alves Meira, 2020.

O LIG Gruta de Ubajara (Figura 8a, b) configura a maior cavidade subterrânea do Ceará, sendo a principal atração turística do PNU. Esculpida em metacalcários da Formação Frecheirinha, dispõe de 1.120 metros de dutos e um rico patrimônio espeleológico endocársticos e exocárstico (estalactites, estalagmites, colunas, travertinos, lapiás, entre outros).

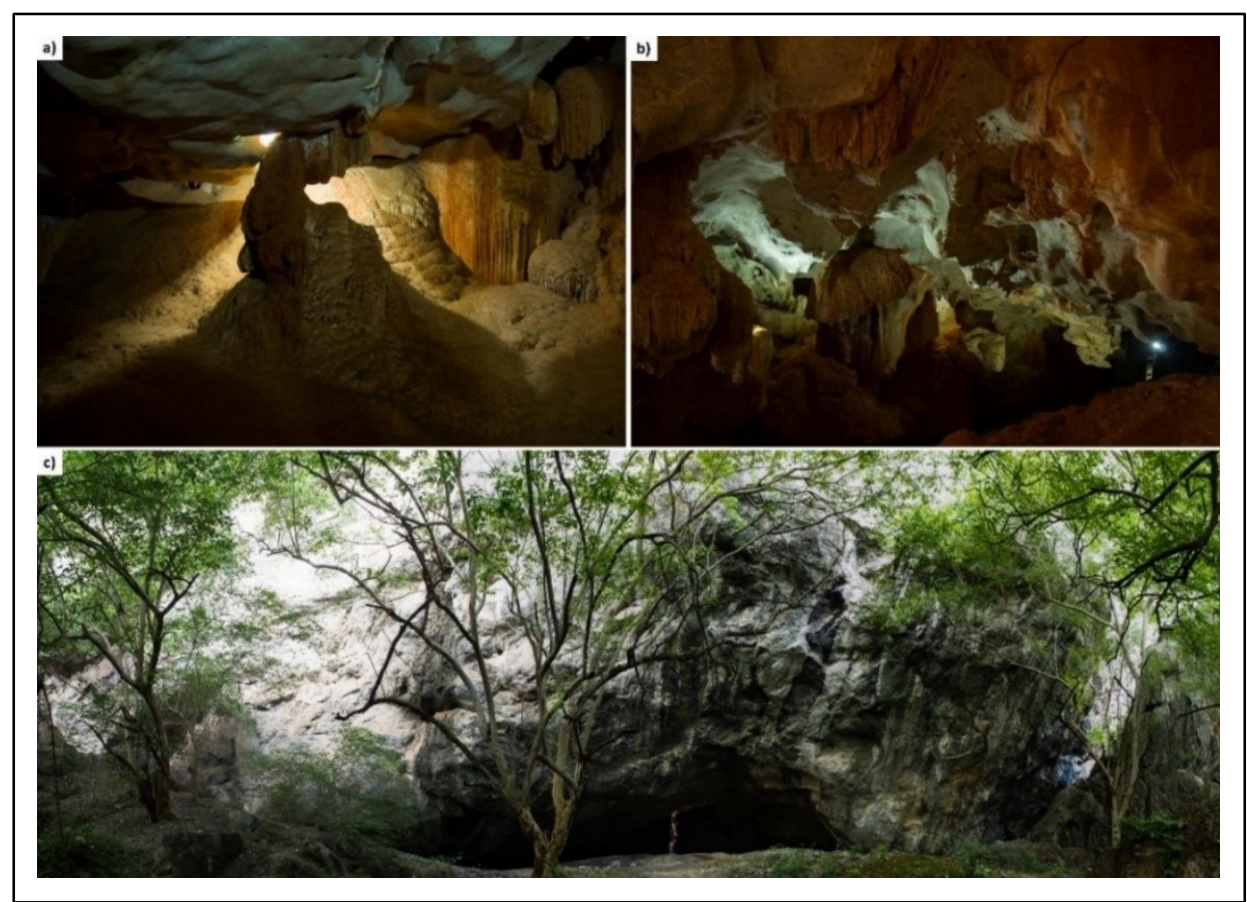

Figura 8 - a, b) Feições endocársticas do LIG Gruta de Ubajara. c) Entrada norte do LIG Furnas de Araticum, salientasse a presença de uma vegetação de porte elevado.

Fotos: Suedio Alves Meira, 2020. 
O LIG Furnas de Araticum (Figura 8c) é caracterizado por um afloramento metacalcário de grandes dimensões (maciço cárstico) em meio à Depressão Sertaneja. Dispõe de cavidades, sendo que o duto principal apresenta desenvolvimento de 272 metros, com presença de abismo e curso hídrico durante a quadra chuvosa.

Após o inventário foi realizado uma avaliação quantitativa com base na metodologia proposta pelo Programa GEOSSIT do Serviço Geológico Brasileiro (CPRM, 2019). Como resultado foram delimitados oito geossítios e três sítios da geodiversidade (SG) (Tabela 1). Foram definidos enquanto geossítios os LIGs que obtiveram valor científico igual ou superior aos 200, sendo eles a Trilha Ubajara-Araticum, os Paredões de Janeiro, a Cachoeira do Pinga, o Mirante da Gameleira, o Mirante do Pendurado, o Circuito das Cachoeiras, a Cachoeira do Pajé e a Gruta de Ubajara.

Tabela 1 - Valores obtidos na avaliação quantitativa dos LIGs inventariados no PNU.

\begin{tabular}{|c|c|c|c|c|c|c|}
\hline LIG & Classificação & $\begin{array}{c}\text { Valor } \\
\text { Científico }\end{array}$ & $\begin{array}{c}\text { Valor } \\
\text { Educativo }\end{array}$ & Valor Turístico & $\begin{array}{c}\text { Risco de } \\
\text { Degradação }\end{array}$ & $\begin{array}{l}\text { Prioridade de } \\
\text { Proteção }\end{array}$ \\
\hline $\begin{array}{c}\text { Trilha } \\
\text { Ubajara- } \\
\text { Araticum }\end{array}$ & $\begin{array}{c}\text { Geossítio de } \\
\text { Relevância Nacional }\end{array}$ & 290 & $\begin{array}{l}275 \text { (Relevância } \\
\text { Nacional) }\end{array}$ & $\begin{array}{l}230 \text { (Relevância } \\
\text { Nacional) }\end{array}$ & $\begin{array}{c}80 \\
\text { (Risco Baixo) }\end{array}$ & $\begin{array}{c}345 \\
\text { (Médio Prazo) }\end{array}$ \\
\hline $\begin{array}{l}\text { Sítio do } \\
\text { Bosco }\end{array}$ & $\begin{array}{c}\text { Sítio da } \\
\text { Geodiversidade de } \\
\text { Relevância Nacional }\end{array}$ & 185 & $\begin{array}{l}325 \text { (Relevância } \\
\text { Nacional) }\end{array}$ & $\begin{array}{l}265 \text { (Relevância } \\
\text { Nacional) }\end{array}$ & $\begin{array}{c}155 \\
\text { (Risco Baixo) }\end{array}$ & $\begin{array}{c}413 \\
\text { (Médio Prazo) }\end{array}$ \\
\hline $\begin{array}{l}\text { Paredões de } \\
\text { Janeiro }\end{array}$ & $\begin{array}{c}\text { Geossítio de } \\
\text { Relevância Nacional }\end{array}$ & 285 & $\begin{array}{l}305 \text { (Relevância } \\
\text { Nacional) }\end{array}$ & $\begin{array}{l}255 \text { (Relevância } \\
\text { Nacional) }\end{array}$ & $\begin{array}{c}120 \\
\text { (Risco Baixo) }\end{array}$ & $\begin{array}{c}402 \\
\text { (Médio Prazo) }\end{array}$ \\
\hline $\begin{array}{c}\text { Cachoeira do } \\
\text { Pinga }\end{array}$ & $\begin{array}{c}\text { Geossítio de } \\
\text { Relevância Nacional }\end{array}$ & 225 & $\begin{array}{c}310 \\
\text { (Relevância } \\
\text { Nacional) }\end{array}$ & $\begin{array}{c}240 \\
\text { (Relevância } \\
\text { Nacional) }\end{array}$ & $\begin{array}{c}135 \\
\text { (Risco Baixo) }\end{array}$ & $\begin{array}{c}393 \\
\text { (Médio Prazo) }\end{array}$ \\
\hline $\begin{array}{l}\text { Mirante da } \\
\text { Gameleira }\end{array}$ & $\begin{array}{c}\text { Geossítio de } \\
\text { Relevância Nacional }\end{array}$ & 260 & $\begin{array}{l}340 \text { (Relevância } \\
\text { Nacional) }\end{array}$ & $\begin{array}{c}300 \text { (Relevância } \\
\text { Nacional) }\end{array}$ & $\begin{array}{c}45 \\
\text { (Risco Baixo) }\end{array}$ & $\begin{array}{c}345 \\
\text { (Médio Prazo) }\end{array}$ \\
\hline $\begin{array}{l}\text { Mirante do } \\
\text { Pendurado }\end{array}$ & $\begin{array}{c}\text { Geossítio de } \\
\text { Relevância Nacional }\end{array}$ & 200 & $\begin{array}{c}355 \\
\text { (Relevância } \\
\text { Nacional) }\end{array}$ & $\begin{array}{c}290 \\
\text { (Relevância } \\
\text { Nacional) }\end{array}$ & $\begin{array}{c}90 \\
\text { (Risco Baixo) }\end{array}$ & $\begin{array}{c}372 \\
\text { (Médio Prazo) }\end{array}$ \\
\hline $\begin{array}{c}\text { Circuito das } \\
\text { Cachoeiras }\end{array}$ & $\begin{array}{c}\text { Geossítio de } \\
\text { Relevância Nacional }\end{array}$ & 200 & $\begin{array}{l}340 \text { (Relevância } \\
\text { Nacional) }\end{array}$ & $\begin{array}{l}300 \text { (Relevância } \\
\text { Nacional) }\end{array}$ & $\begin{array}{c}45 \\
\text { (Risco Baixo) }\end{array}$ & $\begin{array}{c}325 \\
\text { (Médio Prazo) }\end{array}$ \\
\hline $\begin{array}{l}\text { Cachoeira do } \\
\text { Pinguruta }\end{array}$ & $\begin{array}{c}\text { Sítio da } \\
\text { Geodiversidade de } \\
\text { Relevância Nacional }\end{array}$ & 195 & $\begin{array}{c}300 \\
\text { (Relevância } \\
\text { Nacional) }\end{array}$ & $\begin{array}{c}230 \\
\text { (Relevância } \\
\text { Nacional) }\end{array}$ & $\begin{array}{c}105 \\
\text { (Risco Baixo) }\end{array}$ & $\begin{array}{c}347 \\
\text { (Médio Prazo) }\end{array}$ \\
\hline $\begin{array}{c}\text { Cachoeira do } \\
\text { Pajé }\end{array}$ & $\begin{array}{c}\text { Geossítio de } \\
\text { Relevância Nacional }\end{array}$ & 205 & $\begin{array}{l}280 \text { (Relevância } \\
\text { Nacional) }\end{array}$ & $\begin{array}{l}220 \text { (Relevância } \\
\text { Nacional) }\end{array}$ & $\begin{array}{l}235 \text { (Risco } \\
\text { Médio) }\end{array}$ & $\begin{array}{c}470 \\
\text { (Médio Prazo) }\end{array}$ \\
\hline $\begin{array}{l}\text { Gruta de } \\
\text { Ubajara }\end{array}$ & $\begin{array}{c}\text { Geossítio de } \\
\text { Relevância Nacional }\end{array}$ & 290 & $\begin{array}{l}345 \text { (Relevância } \\
\text { Nacional) }\end{array}$ & $\begin{array}{l}315 \text { (Relevância } \\
\text { Nacional) }\end{array}$ & $\begin{array}{c}200 \\
\text { (Risco Médio) }\end{array}$ & $\begin{array}{c}517 \\
\text { (Médio Prazo) }\end{array}$ \\
\hline $\begin{array}{l}\text { Furnas de } \\
\text { Araticum }\end{array}$ & $\begin{array}{c}\text { Sítio da } \\
\text { Geodiversidade de } \\
\text { Relevância Nacional }\end{array}$ & 185 & $\begin{array}{l}315 \text { (Relevância } \\
\text { Nacional) }\end{array}$ & $\begin{array}{l}250 \text { (Relevância } \\
\text { Nacional) }\end{array}$ & $\begin{array}{c}335 \\
\text { (Risco Alto) }\end{array}$ & $\begin{array}{c}585 \\
\text { (Curto Prazo) }\end{array}$ \\
\hline
\end{tabular}

Fonte: Elaborado pelos autores, 2020.

O Sítio do Bosco, a Cachoeira do Pinguruta e as Furnas de Araticum são designadas enquanto sítios da geodiversidade (SGs), por não terem alcançados os 200 pontos no critério científico. Salienta-se que todos obtiveram relevância nacional dentro de suas categorias. Todos os geossítio e SGs alcançaram valor superior 275 pontos no critério educativo e 220 pontos no valor 
turístico, demonstrando a importância dessas áreas para o desenvolvimento de atividades de educação ambiental e de práticas relacionadas ao turismo sustentável (geoturismo).

O risco de degradação (Tabela 1) varia entre baixo e médio, com exceção do SG Furnas de Araticum, que devido estar inserido no perímetro do distrito de Araticum apresenta usos que conferem a necessidade de medidas imediatas de conservação. Tendo como base o potencial de uso e o risco de degradação de cada LIG, foram definidos as prioridades de proteção. Novamente o SG Furnas de Araticum se diferencia, sendo o único que necessita de ações a curto prazo para salvaguardar os elementos de interesse, os demais geossítios e SG, devido ao nível de conservação satisfatório, carecem de medidas a médio prazo.

A avaliação quantitativa configura uma maneira eficiente de diferenciar os locais para quais os esforços de conservação e valorização devem ser orientados. Configura uma forma de apresentar aos gestores do território o potencial ambiental que cada um dos espaços apresenta, bem como as suas vulnerabilidades. Salienta-se que a avaliação quantitativa deve ser agregada a outras ferramentas de cunho qualitativo e deve ser revista periodicamente, uma vez que as condições ambientais podem ser alteradas, tanto positivamente como negativamente, devido ao uso.

\section{SERVIÇOS ECOSSISTÊMICOS DA GEODIVERSIDADE NOS LOCAIS DE INTERESSE GEOLÓGICO DO PARQUE NACIONAL DE UBAJARA}

A avaliação qualitativa da geodiversidade segundo os serviços ecossistêmicos, proposta por Gray (2013), dispõe do valor intrínseco como único, sendo que dele derivam os serviços, os bens e os processos. Assim, todos os elementos abióticos presentes nos geossítios e SG do PNU apresentam valor por sua existência, a qual transcende o julgamento humano quanto ao potencial de uso. Nesse contexto serão expostos os bens e os processos que os locais de interesse geológicos apresentam para o contexto ambiental local e regional.

\subsection{Serviços de suporte}

Os serviços de suporte estão relacionados à capacidade da geodiversidade enquanto substrato para o desenvolvimento da vida (incluindo a humana) e de processos associados, tanto de caráter abiótico como biótico. São destacados três bens e serviços de suporte oferecidos pelos elementos da geodiversidade presentes nos locais de interesse geológicos do PNU, os quais partem do suporte aos processos dos solos, plataforma e na configuração de habitats.

Nos LIGs localizados no Glint da Ibiapaba, como o Geossítio Circuito das Cachoeiras e o SG Sítio do Bosco, os solos apresentam maior espessura (Latossolos) possibilitando a fixação de vegetação de porte elevado (Figura 9). No Geossítio Paredões de Janeiro, mesmo com a existência 
de afloramentos rochosos que resultam em perfis de solo pouco espesso que propicia espécies típicas de ambiente rupestres, há o predomínio de solos profundos. Nesses locais a matéria orgânica é elevada possibilitando a formação de horizontes orgânicos e a maior quantidade de organismos vivos nas camadas superficiais dos solos. No Geossítio Cachoeira do Pajé, devido à declividade não é formado um perfil de solo profundo, mas em decorrência do grande índice pluviométrico local há uma vegetação de porte elevado.

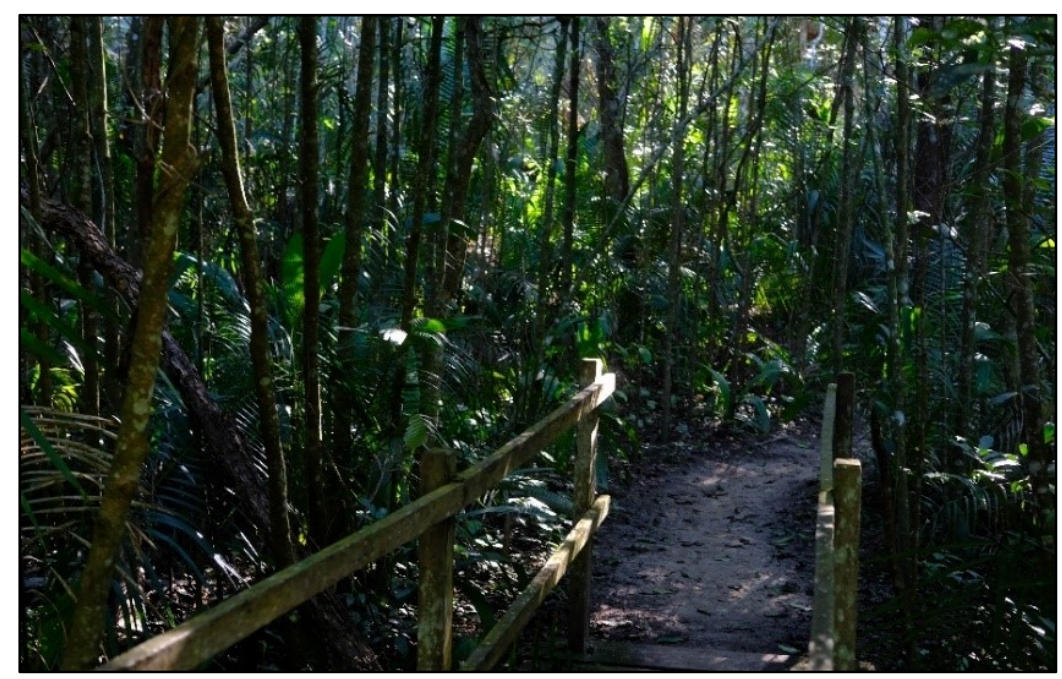

Figura 9 - Mata plúvio-nebular do PNU. Essa vegetação está sobre solos profundos e áreas de maior pluviosidade. Foto: Suedio Alves Meira, 2020.

No Geossítio Trilha Ubajara-Araticum é possível visualizar de forma didática a região saprolítica. Essa característica também é encontrada no Geossítio Cachoeira do Pinga. Nos locais compostos por cavernas, o Geossítio Gruta de Ubajara e o SG Furnas de Araticum, não ocorrem espessos perfis de solo, mas sim, a acumulação de sedimentos de granulometrias variadas, devido a dinâmica erosiva e deposicional diferenciada, bem como a menor ação de agente biológicos.

Os serviços relacionados à plataforma também são encontrados. No SG Sítio do Bosco a Pista de Parapente foi construída sobre a zona de escarpa do glint da Ibiapaba. A estrutura se aproveita da projeção topográfica e a confluência de ventos ascendentes necessárias para a decolagem do parapente. No SG Furnas de Araticum é utilizado para fornos de queima de carvão vegetal, essa atividade é bastante danosa ao ambiente natural regional.

Os geossítios Mirante da Gameleira e Mirante do Pendurado apresentam estruturas de madeira construídas sobre a escarpa, as quais são utilizadas em práticas turísticas e permitem uma melhor visualização da paisagem. No Geossítio Trilha Ubajara-Araticum a trilha, construída com blocos de rochas locais, aproveita zonas de menor declive para realizar o percurso entre o topo da Ibiapaba e a Depressão Sertaneja.

Quanto às configurações de habitats, podem ser delimitadas diferentes escalas de interferência dos elementos da geodiversidade. Numa escala de menor detalhe os geossítios Mirante 
da Gameleira, Mirante do Pendurado e o SG Cachoeira do Pinguruta, devido ao caráter panorâmico, expressa bem como o relevo do Glint da Ibiapaba remete na configuração dos tipos vegetacionais.

As regiões mais elevadas são dotadas de vegetação de porte elevado, que ultrapassam os 20 metros, característicos de matas pluvionebulares, sendo que a medida que a topografia decai em direção à Depressão Sertaneja, passa a ocorrer o predomínio de espécies da caatinga. Distingue-se então três domínios fisionômicos, mata plúvio-nebular, zona de transição e caatinga. Essa mesma diferenciação é vista no Geossítio Trilha Ubajara-Araticum, onde no começo da trilha numa altitude de 800 metros há árvores com copas altas, enquanto que no final do geossítio há uma mescla entre diferentes tipos de vegetação.

Em escala de maior detalhe é possível reconhecer diferenças internas nos sítios, como nos casos do Geossítio Paredões de Janeiro e do SG do Bosco, que além da vegetação de porte elevado apresentam núcleos de vegetação rupestre nas porções de rochas expostas. Por outro lado, esses mesmos afloramentos são suporte para comunidades de musgos e líquens, que devido à alta umidade conseguem se desenvolver. A presença de musgos e líquens também é comum nos afloramentos rochosos presentes no Geossítio Cachoeira do Pinga e no SG Cachoeira do Pajé.

As fendas no Geossítio Paredões de Janeiro são habitadas por morcegos, animal também presente em abundância no Geossítio Gruta de Ubajara e no SG Furnas de Araticum. Esses dois últimos sítios concentram uma diversa fauna cavernícola, diferenciando das regiões externas. As cavernas são um habitat especial no contexto ambiental devido as particularidades do endocarste. Porém, essa diferença também é expressa na área exocársticas, já que o solo oriundo de rochas calcárias permite o desenvolvimento de espécies vegetais de porte arbóreo (Figura 8c), tornando esses afloramentos pontos de alta diversidade biológica. $\mathrm{Na}$ área de pesquisa isso ocorre especialmente nas Furnas de Araticum, a qual se diferencia do seu entorno.

\subsection{Serviços de provisão}

Os serviços de provisão referem à disponibilização de bens materiais para a sociedade, ou seja, como os elementos da geodiversidade são utilizados enquanto objetos para a manutenção da qualidade de vida e enquanto produtos com valor monetário atribuído (SILVA; NASCIMENTO, 2019). Gray (2013) divide esses serviços em bens relacionados ao uso da geodiversidade para fins terapêuticos (saúde), materiais construção, produtos ornamentais, combustíveis, alimentação e bebida e minerais industriais.

Por se tratar de uma Unidade de Conservação de Proteção Integral, as atividades de extração ou utilização em larga escala dos constituintes ambientais estão proibidos no perímetro e dispõe de limitações, segundo normativas do plano de manejo, nas áreas do entorno. Diante disso, 
apesar dos elementos da geodiversidade serem potenciais provedores, os LIGs não disponibilizam esses serviços à sociedade mediante a limitações legais ao uso direto do capital natural.

\subsection{Serviços de conhecimento}

Os serviços de conhecimento são os mais relevantes ao desenvolvimento das Geociências. Representam a potencial da geodiversidade enquanto testemunho da evolução geológica do planeta, assim como na "utilização da natureza abiótica como sala de aula e laboratório" (SILVA; NASCIMENTO, 2017, p. 54). No PNU esses serviços são expressos pela discussão da história da Terra, história da pesquisa, educação e emprego.

No que tange à história evolutiva da Terra os pontos panorâmicos dispostos nos geossítios Mirante da Gameleira, Mirante do Pendurado, Circuito das Cachoeiras, Paredões de Janeiro e nos SGs Cachoeira do Pinguruta e Sítio do Bosco contam a evolução geomorfológica, por meio do entendimento dos processos de aplainamento que propiciaram a geomorfogênese da Depressão Sertaneja e a erosão das vertentes do Glint da Ibiapaba.

O Geossítio Trilha Ubajara-Araticum, por se estender das áreas elevadas até a sopé do Glint da Ibiapaba, configura como um retrato geológico local. Dispõe de afloramentos dos Grupos Serra Grande (Siluriano) e Ubajara (Eocardiano) (Figura 10). Esse geossítio ainda adquire relevância pela presença do icnogênero Planolites Nicholson, em blocos rolados na base da cachoeira do Cafundó, remetendo às características existentes no ambiente durante o período de deposição da rocha.

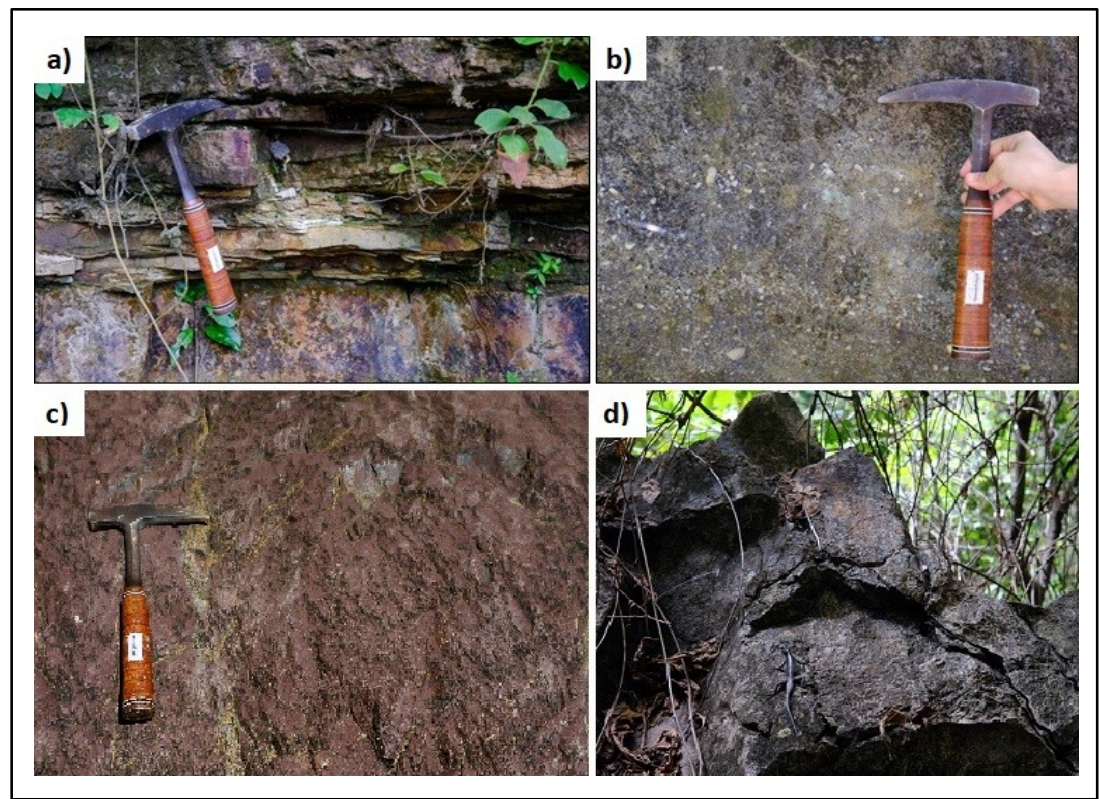

Figura 10 - Diferentes litologias encontradas no Parque Nacional de Ubajara. a) Arenito de grão fino da Formação Tianguá, Grupo Serra Grande. b) Arenito da Formação Tianguá com presença de seixos. c) Ardósia da Formação Caiçaras, Grupo Ubajara. d) Matacalcário da Formação Frecheirinha, Grupo Ubajara.

Fotos: Suedio Alves Meira. 
O Geossítio Cachoeira do Pinga, também devido à sua disposição no decorrer da vertente, propicia a visualização de diferentes estratos do Grupo Serra Grande, sendo passível a sua utilização para a construção de uma coluna estratigráfica.

No que tange à história da pesquisa, o Geossítio Gruta de Ubajara se distingue por ser alvo de trabalhos de diversas áreas (Geologia, Biologia, História etc). Um estudo se destaca nesse critério é a monografia de Pedro Ferreira intitulada "Ubajara, a gruta do Brasil" (FERREIRA, 1958). O autor apresenta uma planta da Gruta de Ubajara no começo do escrito, assinada e datada do ano de 1944, sendo essa acompanhada de uma narrativa que mescla conceitos científicos com conhecimentos históricos e populares. O texto se assemelha a uma carta escrita por um explorador durante o primeiro contato com algo deslumbrante e mágico, o que torna a leitura fluída devido a mescla de linguagens, como é possível visualizar na seguinte passagem:

Da senda íngreme, coleante e seixosa por onde se desce à serra para alcançar a gruta, o observador, confronte e proximadamente à abertura precípua desta se abisma em vera contemplação - ante o soberbo e extasiante panorama do sertão, que se descortina, ao longe, muito ao longe, na orla indecisa do horizonte azulino. Que cousa deslumbrante! (FERREIRA, 1958, sp.).

No que tange à educação, os aspectos abióticos dos locais inventariados são excepcionais para o incremento de atividades de educação ambiental. A visibilidade das feições, a baixa vulnerabilidade em concordância com o nível de proteção legal e o estado de conservação são pontos favoráveis. Quando abordados em conjunto, os LIGs inventariados apresentam temáticas que são passíveis de utilização aos diversos níveis escolares. O valor educativo é salientado pela avaliação quantitativa realizada que classificou todos enquanto de relevância nacional.

Alguns locais de interesse necessitam de maior conhecimento específico em temas das geociências. O Geossítio Trilha Ubajara-Araticum necessita de uma melhor descrição do perfil estratigráfico. O Geossítio Cachoeira do Pinga carece da proposição de um modelo para a sua evolução geomorfológica. Por fim, o Geossítio Paredões do Janeiro, que tem como principal potencial um conjunto de fendas de caráter estrutural, que ainda não apresenta uma explicação definitiva sobre a evolução dessas feições.

Os demais LIGs, em especial os Geossítios Mirante da Gameleira e Mirante do Pendurado, podem ser utilizados até para séries iniciais, alçando de atividades lúdicas diante a diversidade de elementos passíveis de abordagem e a interação com questões de caráter cultural. Salienta-se que essas potencialidades não são aproveitadas como devido, especialmente quando levado em conta que um dos objetivos de um Parque Nacional é a instituição de atividades educativas no seu interior. O PNU é amplamente utilizado como destino de atividades de campo de cursos da área ambiental (Geografia, Geologia, Ciências Ambientais, Turismo etc) de centro de ensino particulares e públicas cearenses, bem como de outros estados, especialmente o Piauí, devido à proximidade. 


\subsection{Serviços de regulação}

Os serviços de regulação compreendem "processos que têm por finalidade o controle natural das condições ambientais, seja do ar, da água e dos solos. Controla a disponibilização destes recursos, sua quantidade e qualidade" (SILVA; NASCIMENTO, 2017, p. 46). Os LIGs prestam serviços aos processos atmosféricos, controle de qualidade da água e processos terrestres.

Os serviços aos processos atmosféricos são marcados pelo papel da geodiversidade no ciclo da água. Os Geossítios Paredões de Janeiros, Cachoeira do Pinga, Trilha Ubajara-Araticum, Cachoeira do Pajé, Circuito das Cachoeiras e o SG Cachoeira do Pinguruta dispõem de cursos hídricos superficiais tanto de caráter perene como intermitente. No Geossítio Gruta de Ubajara há o desenvolvimento de um curso hídrico de caráter criptorréico, que contribui para a evolução geomorfológica, entretanto, o mesmo está localizado na zona intangível da caverna, não sendo acessível para fins turísticos e educativos.

As rochas sedimentares (especialmente, os arenitos) do Grupo Serra Grande dispõem de elevada capacidade hidrogeológica quando levado em conta o contexto regional. A porosidade da rocha é fundamental para absorção e retenção de água da chuva, contribuindo na dinâmica hídrica durante todo o ano. As rochas supracitadas também auxiliam no controle da qualidade da água, já que permite a sua filtragem durante o processo de percolação, tanto que há diversas fontes presentes no decorrer da escarpa apresentam águas cristalinas e potáveis.

Dentre os processos terrestres, há elementos que atuam como armazenadores de carbono. O principal é o solo que opera por meio de processos bióticos no seu interior. Todos os LIGs apresentam potencialidades de acordo as características pedológicas já citadas. Outro aspecto é compreendido pelo ciclo das rochas, pois na área ocorrem rochas sedimentares (Sítio do Bosco, Paredões de Janeiro, Cachoeira do Pinga, Mirante da Gameleira, Mirante do Pendurado, Circuito das Cachoeiras, Cachoeira do Pinguruta, Cachoeira do Pajé e Trilha Ubajara-Araticum) e de rochas metamórficas (Trilha Ubajara-Araticum, Gruta de Ubajara e Furnas de Araticum), remontando assim a diferentes processos e etapas desse ciclo. O Geossítio Trilha Ubajara-Araticum ainda pode ser destacado pela sua localização em meio a depósitos coluvionares, o qual remete ao processo de remoção e deposição de sedimentos.

\subsection{Serviços culturais}

Os serviços culturais compreendem as relações e os significados que um grupo social atribui aos elementos da geodiversidade, ou seja, essa enquanto reflexo e agente na construção da identidade local. Esses componentes podem e devem ser utilizados pelos órgãos gestores das UCs enquanto justificativa ao desenvolvimento de atividades turísticas e de educação ambiental, uma 
vez que carregam no seu bojo a noção de pertencimento. No âmbito dos LIGs inventariados são distinguidos bens relacionados ao geoturismo e lazer, inspiração artística, qualidade ambiental, desenvolvimento social e significado natural, histórico e cultural.

Quanto ao lazer todos os sítios inventariados já são aproveitados por práticas turísticas em maior ou menor grau. Os elementos da geodiversidade são utilizados enquanto produto turístico, seja por meio da apreciação nos mirantes, as visitas às cavernas, ou mesmo, o banho nas cachoeiras. A tipologia turística empregada é caracterizada pelo ecoturismo, uma vez que o foco perpassa pelo contato com a natureza por meio da valorização dos aspectos da biodiversidade. Entretanto os locais apresentam potencialidades para a instituição de atividades geoturísticas, o que viria dinamizar a oferta de serviços e as interações com os aspectos culturais e abióticos da paisagem.

Distingue-se dois grupos entre os locais inventariados, aqueles que já dispõem de infraestrutura turística, sendo compostos pelos geossítios Mirante da Gameleira, Mirante do Pendurado, Circuito das Cachoeiras, Trilha Ubajara-Araticum, Gruta de Ubajara (de âmbito público) e o SG Sítio do Bosco (de caráter particular) e os que não dispõem de infraestrutura básica, sendo eles os geossítios Paredões de Janeiro, Cachoeira do Pajé, Cachoeira do Pinga e os SGs Cachoeira do Pinguruta e Furnas de Araticum. Independente do aparato já instituído nota-se as potencialidades paisagísticas relacionadas aos aspectos abióticos, compostos por escarpas, afloramentos rochosos, cachoeiras, cavernas, campos de lapiás, entre outros.

Quanto à inspiração artística as paisagens do PNU têm sido utilizadas enquanto base para expressões por meio de quadros, artesanatos, poesias e músicas. A monografia de Ferreira (1958) sobre a Gruta de Ubajara, citada anteriormente, pode ingressar nesse ponto, por transitar entre a ciência e a literatura. Programas de televisão de circulação regional e nacional já tiveram como tema o Parque Nacional e abordaram locais como os geossítios Mirante da Gameleira, Paredões de Janeiro, Gruta de Ubajara e Circuito das Cachoeiras.

Silva e Nascimento (2017, p. 53) expõem que o aspecto da qualidade ambiental se refere principalmente ao apelo estético da paisagem e representa o quanto a "diversidade natural dos elementos abióticos constitui um local em que há benefícios psicológicos ou físiológicos para o ser humano, melhorando a vida das pessoas de forma não material”. Nesse contexto, é difícil de quantificar o critério, uma vez que a percepção é intrínseca ao visitante.

Os locais inventariados apresentam apelo cênico, seja pela dimensão das feições (escarpas, cachoeiras, cavernas, entre outras) ou devido ao nível de conservação, com exceção do SG Furnas de Araticum. Outro aspecto é o caráter isolado dos locais que permitem momentos de imersão na natureza, com ressalva aos SGs Sítio do Bosco e das Furnas de Araticum. Os geossítios Circuitos das Cachoeiras, Cachoeira do Pinga, Cachoeira do Pajé, Paredões de Janeiro e o SG Cachoeira do Pinguruta, acrescentam um potencial devido à presença de cachoeiras e a mística em seus banhos. 
Os locais inventariados apresentam significado natural pelo apelo cênico das feições geomorfológicas e por sua relevância na dinâmica ambiental local. Quanto ao aspecto histórico os geossítios Paredões de Janeiro, Cachoeira do Pinga e Trilha Ubajara-Araticum configuram-se como caminhos entre as áreas rebaixadas do "sertão" e o topo do Glint da Ibiapaba, os quais foram empregados por diferentes povos indígenas e colonizadores. A trilha Ubajara-Araticum ainda figura como um dos acessos entre a sede municipal de Ubajara e o distrito de Araticum, sendo utilizado especialmente por vendedores de carvão que sobem a serra em busca de compradores.

Quanto ao aspecto cultural, é válido salientar que muito se perdeu após o processo de desapropriação ocorrido no antigo perímetro do PNU, uma vez que a moradia e as atividades religiosas foram banidas do interior da UC. Porém, rugosidades físicas e mentais ainda permanecem desse período, seja pelas lendas envolvendo o Morro do Pendurado, ou pelo cruzeiro localizado no começo da trilha Ubajara-Araticum, marcando o local utilizado como ponto de oração e realização das missas que marcavam o começo da procissão até a Gruta de Ubajara. Seja pelas ruínas das casas ou as enormes mangueiras (planta não nativa, mas disseminada pelos antigos moradores) localizadas nas trilhas que levam ao Geossítio Circuito das Cachoeiras. Pela toponímia do salão de entrada da Gruta de Ubajara, denomina “Sala da Imagem”, já que lá se encontrava uma imagem de Nossa Senhora, sendo o salão utilizado para missas, casamentos e batizados.

Por não estar inserido no perímetro do PNU, o SG Furnas de Araticum ainda é bastante utilizado por práticas tradicionais, em especial para a queima de lenha para fabricação de carvão vegetal. No entorno da feição são encontrados grandes buracos no solo onde é realizada a queima, essa atividade tradicional é bastante nociva a natureza, já que vegetação predominante do entorno, a caatinga, tem baixa capacidade calorífica devido as suas características fitofisionômicas.

Os bens relacionados ao desenvolvimento social parte do uso de alguns LIGs em atividades turísticas que geram benefícios econômicos a diferentes agentes do território. Nesse ponto se desta o SG Sítio do Bosco e os espaços localizados no antigo perímetro do PNU. Como citado, o SG Sítio do Bosco é uma propriedade particular utilizada em atividades relacionadas ao ecoturismo, apresenta diferentes produtos e atrativos, sendo um dos principais destinos no município de Tianguá. O desenvolvimento dessa prática só é possível devido a beleza cênica que os elementos da geodiversidade apresentam. Tal fato também ocorre nos geossítios Mirante do Pendurado, Mirante da Gameleira, Circuito das Cachoeiras, Trilha Ubajara-Araticum e Gruta de Ubajara que são os principais atrativos turísticos do PNU.

A tabela 2 apresenta o resumo dos serviços, bens e processos ecossistêmicos prestados pelos elementos da geodiversidade presentes nos geossítios e sítios de geodiversidade do PNU. É possível notar a diversidade e a variabilidade de serviços que cada local presta, isso passa pelas diferentes escalas de análise e pela riqueza geológica e geomorfológica que cada local apresenta. 
Tabela 2 - Serviços, bens e processos ecossistêmicos prestados por elementos da geodiversidade dos Locais de Interesse Geológico do Parque Nacional de Ubajara segundo proposta de Gray (2013).

\begin{tabular}{lccccccccccc}
\hline \multicolumn{10}{c}{ SERVIÇOS } & \multicolumn{10}{c}{ GEOSSÍTIOS* } \\
\hline \multicolumn{1}{c}{ Suporte } & GTU & SSB & GPJ & GCPi & GMG & GMP & GCC & SCP & GCPa & GGU & SFA \\
\hline Processos de solo & & & & & & & & & & \\
Habitat & X & X & X & X & X & X & X & X & X & \\
Plataforma & X & X & X & X & XX & X & X & X & X & X & X \\
Sepultamento e armazenamento & & & & & X & X & & & & & X \\
\hline
\end{tabular}

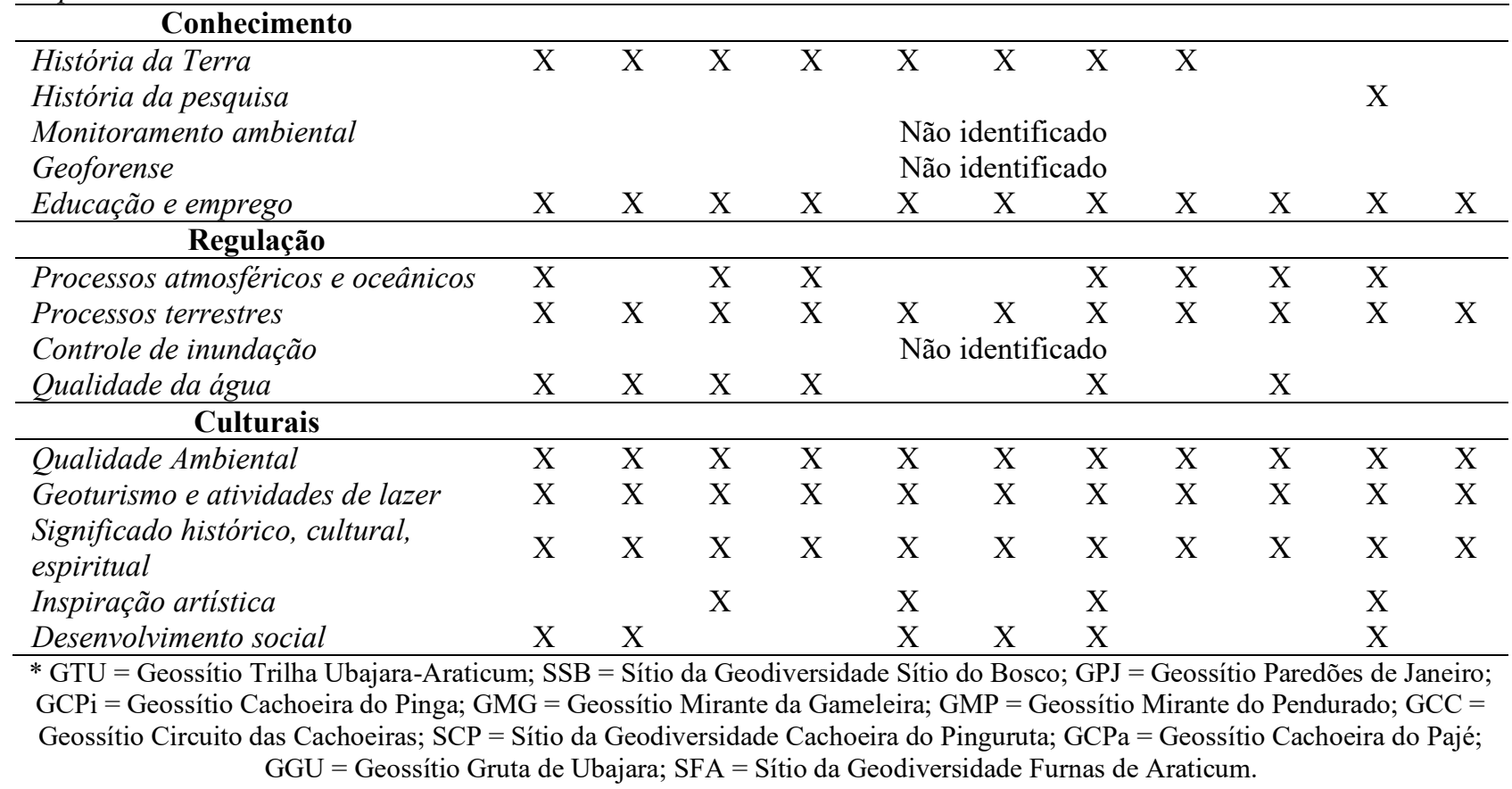

Fonte: Elaborado pelos autores, 2020.

Com o exposto percebe-se a necessidade de que os gestores públicos, os agentes do trade turístico/econômico e a comunidade compreendam que esses espaços são fundamentais para a manutenção da qualidade ambiental e social regional. Nesse contexto, é válido a formulação de propostas que integrem o arcabouço teórico gerado com ações de caráter prático de valoração e valorização ambiental.

\section{VALORAÇÃO DE SERVIÇOS ECOSSISTÊMICOS DA GEODIVERSIDADE EM ÂMBITO LOCAL: PROPOSTAS PARA O PARQUE NACIONAL DE UBAJARA}

O Parque Nacional de Ubajara apresenta diferentes dificuldades no que tange à fiscalização e à conservação. Desafios comuns em outras UCs brasileiras estão presentes, como o combate à caça e às queimadas, sendo que a presença de população no entorno imediato (povoados, distritos e as sedes urbanas de Tianguá e Ubajara) potencializa essa problemática em vez de agir enquanto agentes de salvaguarda, o que ocorre quando não há medidas direcionadas de educação ambiental.

O plano de manejo (ICMBio, 2002) aponta questões internas e externas que contribuem para o insucesso do programa de conservação. No âmbito interno a escassez de recursos humanos e financeiros impossibilita o desenvolvimento de ações de monitoramento mais efetivas. Já os fatores 
externos são alicerçados na ausência de políticas públicas ambientais regionais, o desmatamento nas áreas do entorno e a insuficiência nas atividades de educação ambiental. É válido salientar, que o perímetro expandido é o mais susceptível aos processos de degradação ambiental, devido à ausência de cercamento e limitação de acesso, por não ter passado pela etapa de desapropriação e a distância das guaritas de monitoramento.

Nesse sentido, o presente artigo apresenta algumas propostas de caráter direto, por meio da construção de infraestruturas e readequação de trilhas, e de cunho indireto, incentivando o diálogo com a população. As propostas entendem os LIGs enquanto áreas funcionais, ou seja, porções de trânsito de pessoas e de uso para atividades turísticas e educativas no contexto do zoneamento. Os LIGs são então espaços que prestam serviços ambientais à sociedade e passíveis de serem utilizados na arrecadação de fundos que sejam revertidos à conservação. A dispersão dos LIGs nas diferentes porções do PNU é um critério que favorece o uso enquanto base para ações de conservação, podendo assim atingir diferentes públicos.

O primeiro projeto formulado é intitulado Nas trilhas do Parque Nacional de Ubajara e preza pela readequação de trilhas e construção de infraestruturas nas suas proximidades. São delimitadas três trilhas prioritárias: Trilha dos Paredões de Janeiro; Trilha da Transumância (Geossítio Cachoeira do Pinga); e, Trilha da Cachoeira do Pinguruta. A trilha do Geossítio Paredões de Janeiro necessita de readequações quanto ao trajeto e a sinalização, uma vez que não há quaisquer materiais interpretativos que indique ao visitante a sua presença em uma UC. É incentivada a fixação desses elementos, sobretudo diante a ausência de controle direto de visitantes, nesse contexto as infraestruturas cumpririam o papel de sensibilizar os visitantes.

As trilhas da Transumância e da Cachoeira do Pinguruta apresentam as mesmas fragilidades citadas. Carecem de adequação do trajeto e da interpretação das potencialidades. Atualmente quem visita esses geossítios o faz pelo apelo cênico local, não havendo qualquer incentivo à conservação. Com as adequações essas trilhas exerceriam uma nova função junto à educação ambiental informal, bem como às atividades turísticas, uma vez que seriam produtos diferenciados no contexto regional.

Os temas relacionados ao geopatrimônio e suas interações com os serviços ecossistêmicos podem ser a base para a elaboração dos materiais interpretativos. Por sua vez, o financiamento para a construção das infraestruturas pode ser angariado junto à iniciativa privada regional por meio de incentivos à "adoção" de uma trilha. Ações semelhantes são comuns em centros urbanos, onde empresas adotam uma praça ou refúgio verde, realizando a manutenção periódica e a fixação de equipamentos. Em contrapartida, a marca da empresa é vinculada nos materiais interpretativos.

O projeto Casa amiga do Parque Nacional de Ubajara cumpre o papel de aproximar a gestão do PNU e os moradores das áreas do entorno, suavizando conflitos oriundos do processo de 
desapropriação (ARAÚJO, 2004) e diluindo o "mito" da natureza intocável (DIEGUES, 2001) ao inseri-los enquanto parte do meio ambiente. Esse projeto deve ser pensado por meio da abordagem dos bens e serviços prestados pelos aspectos ambientais do parque, tanto biótico como abióticos, fazendo com que as pessoas entendam a necessidade de conservá-los.

As comunidades, no contexto histórico atual, não podem ser encaradas enquanto inimigas das áreas protegidas, mas sim enquanto meio para a conservação, valorização e divulgação dessas. Nesse contexto, o projeto propõe parcerias entre a gestão e as comunidades próximas aos LIGs, para que esses atuem como "guardadores" ambientais. O PNU já realiza ações de cooperação UCComunidade, sobretudo para o recenseamento de visitantes em áreas não cercadas. O projeto visa ampliar essas ações por meio da aplicação de cursos de capacitação em educação e monitoria ambiental, assim como de empreendedorismo, fazendo a população enxergar na conservação ambiental uma possibilidade de ganho financeiro por meio da venda de produtos aos visitantes.

As casas parceiras do projeto seriam identificadas com placas padronizadas com os dizeres “Essa casa é amiga do Parque Nacional de Ubajara” e passariam por ações de comunicação junto aos projetos turísticos do parque. A comunicação é uma parte importante, uma vez que os frutos a serem colhidos pela comunidade dependem da divulgação das suas ações realizadas e dos produtos disponíveis, criando uma rede de incentivo ao turismo de base local. Por meio da comunicação efetiva, os visitantes ao se depararem com a placa irão entender a importância e os serviços que aquela casa presta para a conservação ambiental do local.

Nos projetos supracitados não há, no entendimento tradicional, um Pagamento por Serviços Ambientais, uma vez que nenhum montante monetário será dirigido ao órgão gestor do PNU. Entretanto, há uma apropriação do capital natural local, ou seja, dos serviços ecossistêmicos prestados para o marketing ambiental e o estabelecimento de uma relação mais simbiótica da sociedade, possibilitando o crescimento de atividades de cunho conservacionistas.

Os projetos propostos necessitam de recursos financeiros e humanos para a sua realização. A carência de recursos é uma realidade na maioria das UCs brasileiras, dentre as oito fraquezas mais debilitantes do PNU estão apontadas a insuficiência de recursos humanos e financeiros (ICMBio, 2002). Esse fato impossibilita o aprofundamento de ações relacionadas à educação ambiental, à interação com a população, bem como a diminuição dos índices de conservação.

Como conservar se não há verba para isso? Essa é uma questão basilar na gestão de UCs. O PNU não dispõe de orçamento fixo, ficando à mercê de repasses públicos para o desenvolvimento das suas atividades. O Instituto Chico Mendes de Conservação da Biodiversidade é o órgão responsável pelo repasse das verbas, realizando o pagamento da folha de pessoal (efetivos e terceirizados) e de serviços (água, energia, entre outros). O PNU também conta com recursos de compensação ambiental, que quando disponíveis, são destinados para reformas e melhorias de 
infraestruturas. A Cooperativa de Trabalho, Assistência ao Turismo e Prestação de Serviços Gerais (COOPTUR) é responsável pela prestação de serviços relacionados ao turismo, sendo que toda a verba arrecada com entradas e passeios guiados é revertida para a manutenção da cooperativa e dos seus associados, não havendo repasse de recurso para a gestão do PNU. A seguir são propostas ações tendo como base exemplos de outras UCs públicas que conseguiram aumentar a arrecadação de divisas por meio de ações de empreendedorismo e incentivo ao entendimento do valor dos serviços ambientais prestados.

O primeiro projeto proposto é intitulado Empreendimento amigo do Parque Nacional de Ubajara e compreende a criação de um selo para empresas que contribuírem com ações de educação ambiental, melhorias de infraestruturas e incremento ao turismo na área do parque. Os empreendimentos particulares seriam convidados a adotar um determinado geossítio, ou um painel interpretativo, ou mesmo uma ação educativa em uma escola. Essa ação propiciaria a construção e a manutenção de equipamentos e a melhoria das atividades turísticas e educativas. Esse projeto deve andar lado a lado com os sugeridos anteriormente (especialmente o projeto Nas trilhas do Parque Nacional de Ubajara).

A gestão do PNU deve apresentar um projeto para as possíveis empresas parceiras, abordando as características gerais e as contrapartidas. Deve-se buscar empresas com perfis paralelos ao do PNU, ou seja, que apresentam preocupação com questões ambientais, uma vez que a marca estará atrelada às atividades realizadas na unidade. Firmada a parceria a empresa receberá um certificado e terá a sua identidade visual disponibilizada no equipamento "adotado". Esse projeto pode ser ampliado para as secretarias de turismo, meio ambiente e desenvolvimento social de Frecheirinha, Tianguá e Ubajara. Visando arrecadação de verba junto a fundos municipais específicos. É necessário que o projeto apresentado às empresas disponha de explanações sobre os bens e serviços ambientais prestados pelo PNU, já que essas informações apresentam a capacidade de sensibilizar, uma vez que só conservamos aquilo que conhecemos. A sensibilização e a educação da população, em conjunto com o marketing ambiental é fundamental para o sucesso do projeto.

O projeto "Quanto vale a sua visita?" tem como premissa o pagamento voluntário por parte dos visitantes pelos serviços ambientais prestados pelo PNU. O projeto tem como aporte a técnica de valoração ambiental da Disposição a Pagar. Durante as visitas aos LIGs serão apresentados os bens e os serviços ecossistêmicos oferecidos e ao final do passeio serão expostos os pressupostos e a finalidade do projeto. Deve-se apresentar ao visitante os objetivos do projeto, os quais partem da arrecadação de valores monetários de forma voluntária para reverter em ações de conservação e educação ambiental.

Os projetos de angariação de recursos configuram uma das chaves de sucesso para a efetivação da conservação e valorização do geopatrimônio do PNU. Apesar de serem os últimos 
abordados as suas ações devem preceder aos demais, já que para a realização dos mesmos é necessário, para além da boa vontade pública e política, a presença de aporte financeiro.

\section{CONSIDERAÇÕES FINAIS}

A abordagem do capital natural pela ótica dos serviços ecossistêmicos configura uma ação válida à manutenção ambiental uma vez que busca unir dois aspectos que parecem antagónicos, o do desenvolvimento econômico e o da conservação. Entender os valores de uso da natureza e discutir a sua relevância para o mantimento da qualidade de vida da sociedade é fundamental para a sensibilização dos agentes gestores do território. É necessário entender que o capital humano, mesmo com toda o progresso das técnicas que ocorreram após a revolução industrial, não é capaz de suprir os serviços prestados pelo capital natural (ANDRADE et al., 2012).

Os serviços ambientais devem ser concebidos em uma visão holística, onde a diversidade dos elementos ambientais e dos processos integrantes são fundamentais para a sua efetivação. Assim, para pensar os bens e os serviços ecossistêmicos é necessário conceber as funções que os elementos da geodiversidade oferecem, indo além do papel de suporte. A geodiversidade deve ser abordada enquanto um conjunto de componentes com toda uma gama de serviços passíveis de serem quantificados e valorados para medidas efetivas de conservação e sensibilização ambiental.

Os elementos da geodiversidade dos Locais de Interesse Geológico do Parque Nacional de Ubajara prestam uma variedade de serviços que contribuem a manutenção da qualidade de vida da sociedade. São serviços de suporte, conhecimento, regulação e culturais que destacam os geossítios e sítios da geodiversidade presentes enquanto espaços prioritários para a conservação, mas também para o uso em atividades educativas e científicas.

Pensar a valoração desses bens e serviços ecossistêmicos podem ser realizadas de diferentes maneiras, uma dela é por meio de métodos de abrangência regional disponíveis na literatura e normativas nacionais e internacionais. Entretanto, as propostas formuladas trazem a importância de pensar o local, de pensar nas pessoas que vivem esse espaço, concebendo os agentes que modificam de forma direta o território. As propostas salientam a importância do conhecimento, da educação, do marketing e da angariação de recursos financeiros na ampliação das medidas de conservação.

Salientasse que as propostas são adaptadas à realidade social e econômica do Parque Nacional de Ubajara e seu entorno, bem como às limitações normativas de uso do território referentes à essa tipologia de unidade de conservação. Sendo assim, as ideias lançadas configuram um incentivo ao pensar os serviços ecossistêmicos pelo âmbito local, e não enquanto um conjunto de propostas a serem replicadas ipis litteris. As dificuldades de conservação que muitas áreas 
protegidas brasileiras enfrentam, oriundas de défice financeiro, diminuto capital humano, ausência de atividades educativas ou desconhecimento da importância pela população local, devem ser enfrentadas também por meio de ações que partem do âmbito local e não apenas por diretrizes que transcendem os seus limites administrativos.

\section{REFERÊNCIAS}

ANDRADE, D. C.; ROMEIRO, A. R. Capital natural, serviços ecossistêmicos e sistema econômico: rumo a uma "Economia dos Ecossistemas". Texto para Discussão, São Paulo, n. 159, p. 1-23, 2009.

ANDRADE, D. C.; ROMEIRO, A. R.; SIMÕES, M. S. From an empty to a full world: a nova natureza da escassez e suas implicações. Economia e Sociedade, Campinas, v. 21, n. 3, p. 695-722, 2012.

ARAÚJO, V. T. O entorno do Parque Nacional de Ubajara-CE: Caracterização socioambiental do distrito de Araticum. 2004. 128 f. Dissertação (Mestrado em Desenvolvimento e Meio Ambiente) - Centro de Ciências, Universidade Federal do Ceará, Fortaleza, Ceará, 2004.

BRILHA, J. Inventory and Quantitative Assessment of Geosite and Geodiversity Sites: a Review. Geoheritage, Suíça, n. 2, v. 8, p. 119-134, 2016.

CAPUTO, M. V.; LIMA, E. C. Estratigrafia, idade e correlação do Grupo Serra Grande - Bacia do Parnaíba. In: CONGRESSO BRASILEIRO DE GEOLOGIA, 33, 1984, Rio de Janeiro. Anais... Rio de Janeiro: 1984. p. 740-753.

CAVAlCANTE, J. C. Estratigrafia Precambriana do Estado do Ceará - Uma síntese. In: SIMPÓSIO DE GEOLOGIA DO NORDESTE, 1, 1993, Natal. Atas... Natal: Núcleo Nordeste da SBG, p. 313-316, 1993.

COSTANZA, R.; D'ARGE, R.; GROOT, R.; FARBER, S.; GRASSO, M.; HANNON, B.; LIMBURG, K.; NAEEM, S.; O’NEILL, R.; PARUELO, J.; RASKIN, R. G.; SUTTON, P.; BELT, M. V. D. The value of the world's ecosystem services and natural capital. Nature, v. 387, p. 253260, 1997.

CPRM. Geossit: cadastro de sítios geológicos. Disponível em: http://www.cprm.gov.br/geossit. Acesso em: 27 nov. 2019.

DIEGUES, A. C. S. O mito moderno da natureza intocada. 3. ed. São Paulo: Editora Hucitec, 2001. 169p.

FERREIRA, P. Ubajara, a gruta do Brasil. Monografia. Fortaleza, 1958. Disponível em: www.bibliotecadigital.gpme.org.br/bd/wp-content/uploads/eco/pdf/bd-gpme-0277.pdf. Acesso em: 27 nov. 2019.

GARCIA-CORTÉS, A.; CARCAVILLA URQUÍ, L. C. Documento metodológico para la elaboracíon del inventario Español de lugares de interés geológico (IELIG). Madrid: Instituto geológico y minero de España, 2013. 64p. 
GORDON, J. E.; BARRON, H. F. Valuing geodiversity and geoconservation: developing a more strategic ecosystem approach. Scottish Geographical Journal, Escócia, v. 128, n. 3, p. 278-297, 2012.

GRAY, M. Geodiversity: valuing and conserving abiotic nature. 1. ed. Chichester: John Wiley and Sons, 2004. 434p.

GRAY, M. Geodiversity: valuing and conserving abiotic nature. 2. ed. Chichester: John Wiley and Sons, 2013. 495p.

GUERRY, A. D.; POLASKY, S.; LUBCHENCO, J.; CHAPLIN-KRAMER, R.; DIARIAMENTE, G. C.; GRIFFIN, R.; RUCKELSHUS, M.; BATEMAN, I. J.; DURAIPPAH, A.; ELMGVIST, T.; FELDMAN, M. W.; FOLKE, C.; HOEKSTRA, J.; KAREIVA, P. M.; KEELER, B. L.; LI, S.; MCKENZIE, E.; OUVANG, Z.; REYERS, B.; RICKETTS, T. H.; ROCKSTROM, J.; TALLIS, H.; VIRA, B. Natural capital and ecosystem services informing decisions: From promise to practice. PNAS, Estados Unidos da América, v. 112, n. 24, p. 7348-7355, 2015.

HERCOWITZ, M.; MATTOS, L. M.; SOUZA, R. P. Estudos de casos sobre serviços ambientais. In: NOVION, H.; VALLE, R. (Org). É pagando que se preserva?: subsídios para políticas públicas de compensação por serviços ambientais. São Paulo: Instituto Socioambiental. 2009. cap. 7. p. 136-240.

ICMBIO. Plano de manejo do Parque Nacional de Ubajara: Encarte 6, Planejamento. Brasília: Ministério do Meio Ambiente, 2002, 138p.

PARRON, L. M.; GARCIA, J. R. Serviços ambientais: conceitos, classificação, indicadores e aspectos correlatos. In: PARRON, L. M.; GARCIA, J. R.; OLIVEIRA, E. B.; BROWN, G. G.; PRADO, R. B. Serviços ambientais em sistemas agrícolas e florestais do bioma Mata Atlântica. Brasília: Embrapa, 2015. cap. 1. p. 29-35.

SANTOS, M. 1992: A redescoberta da natureza. Estudos Avançados, São Paulo, v. 16, n. 14, p. 95-106, 1992.

SHARPLES, C. A. Concepts and principles of geoconservation. Tasmanian Parks and Wildlife Service Website. 2002. Disponível em: http://dpipwe.tas.gov.au/Documents/geoconservation.pdf. Acesso em: 21 nov. 2019.

SIQUEIRA, A. C. A. Geoquímica das lateritas do Domínio Médio Coreaú - Noroeste do estado do Ceará. 2011. 93 f. Dissertação (Mestrado em Geologia) - Centro de Ciências, Departamento de Geologia, Universidade Federal do Ceará, Fortaleza, 2011.

SILVA, M. L. N.; NASCIMENTO, M. A. L. Os valores da Geodiversidade de acordo com os serviços ecossistêmicos sensu Murray Gray aplicados a estudo in situ na cidade de Natal (RN). Cadernos de Geografia, Belo Horizonte, v. 26, n. esp. 2, p. 338-354, 2016.

SILVA, M. L. N.; NASCIMENTO, M. A. L. Geodiversidade da cidade do Natal/RN - Nordeste do Brasil: valores, classificações e ameaças. 1. ed. Beau-Bassin: Novas Edições Acadêmicas, 2017. $181 \mathrm{p}$. 
SILVA, M. L. N.; NASCIMENTO, M. A. L. O sistema de valoração da geodiversidade, com enfoque nos serviços ecossistêmicos sensu Murray Gray. Bol. Mus. Para. Emílio Goeldi. Cienc. Nat., Belém, v. 14, n. 1, p. 79-90, 2019.

VAZ, P. T.; REZENDE, N. G. A. M.; WANDERLEY FILHO, J. R.; TRAVASSOS, W. A. S. Bacia do Parnaíba. Boletim de Geociências da Petrobrás, Brasília, v. 15, n. 2, p. 253-263, 2007.

Trabalho enviado em $04 / 02 / 2020$

Trabalho aceito em 28/07/20 